\title{
JG|U
}

Gutenberg School of Management and Economics \& Research Unit "Interdisciplinary Public Policy"

Discussion Paper Series

\section{More Female Manager Hires through More Female Managers? Evidence from Germany}

Mario Bossler, Alexander Mosthaf, and Thorsten Schank

September 21, 2016

Discussion paper number 1618 
Contact Details:

Mario Bossler

Institute for Employment Research LASER

Regensburger Straße 104

90478 Nürnberg

mario.bossler@iab.de

Alexander Mosthaf University of Mainz

Chair of Applied Statistics and Econometrics

Jakob-Welder-Weg 4

55128 Mainz

mosthaf@uni-mainz.de

Thorsten Schank

University of Mainz; IWH, IZA and LASER

Jakob-Welder-Weg 4

55128 Mainz

schank@uni-mainz.de 


\title{
More female manager hires through more female managers? Evidence from Germany*
}

\author{
Mario Bossler ${ }^{\dagger}$ \\ Alexander Mosthaf $f^{\ddagger}$ \\ Thorsten Schank ${ }^{\S}$
}

September 21, 2016

\begin{abstract}
This paper investigates if there is state dependence in the gender composition of managers in German establishments. We analyze whether the number of hired female managers (respectively the share of females within hired managers) depends on the past hiring decisions of an establishment. Using administrative data, we apply dynamic linear models and dynamic tobit models accounting for unobserved heterogeneity and the endogeneity of lagged dependent variables. We find that an increase of female manager hires in present leads to more female hired managers in the future. Similarly, the number of male manager hires also exhibits state dependence. [97 words]
\end{abstract}

Keywords: female managers; gender discrimination; state dependence; dynamic panel data models

JEL-Classification: C23, J16, J71, M12

${ }^{*}$ We gratefully acknowledge comments by Annette Bergemann, Michael Oberfichtner and those received at the following presentations: seminars at the universities of Darmstadt, Mainz, Nottingham, Würzburg and at the Halle Institute for Economic Research (IWH), Comparative Analysis of Enterprise Data (CAED) Conference in Istanbul, Jahrestagung des Ausschusses für Bevölkerungsökonomik (Freiburg), European Society for Population Economics (ESPE) conference in Berlin, Gender Gaps Conference in Warsaw, Annual Meeting of the German Economic Association (Verein für Socialpolitik) in Augsburg and European Association of Labor Economists (EALE) conference in Ghent (Belgium).

${ }^{\dagger}$ Institute for Employment Research; LASER; Regensburger Straße 104; 90478 Nürnberg; mario.bossler@iab.de

$\ddagger$ University of Mainz; Jakob-Welder-Weg 4; 55128 Mainz; mosthaf@uni-mainz.de

$\S$ University of Mainz; IWH, IZA and LASER; Jakob-Welder-Weg 4; 55128 Mainz; schank@unimainz.de 


\section{Introduction}

Women are heavily under-represented in management positions, a phenomenon often referred to as glass ceiling. In the US, for example, only 21 percent of senior managers are female (Grant Thornton, 2015). Likewise, in Germany the share of females within managers at the middle and upper level is only 32 percent. ${ }^{1}$ Moreover, only 6.5 percent of managers on the board of directors of the 160 firms listed in the main German stock market indices are female and the female share within the supervisory boards of these firms amounts only to 25 percent (FidAR, 2016). ${ }^{2}$

Analyzing female representation among managers is important as manager positions come along with increased wages (McCue, 1996; Lima and Pereira, 2003) and high job satisfaction (Kosteas, 2011). In addition, female representation in managerial positions is important as it also affects labor market outcomes of females in non-managerial positions. For instance, there is evidence that female managers reduce perceived discrimination and improve the work-life balance of female workers (Lucifora and Vigani, 2016). Moreover, the empirical literature has shown that female managers lead to a decrease in the gender wage gap and to an increase in the chance of female non-managers to get hired (Hultin and Szulkin, 2003; Cohen and Huffman, 2007; Cardoso and Winter-Ebmer, 2007; Hirsch, 2013; Hensvik, 2014). Here, the middle management plays a major role, because they are more involved in interactions with non-managerial staff (Hirsch, 2013). At the macro level, the resulting reallocation could potentially have important effects on aggregate productivity. ${ }^{3}$

\footnotetext{
${ }^{1}$ Own calculations based on the Integrated Employment Biographies.

${ }^{2}$ Against this background, in March 2015 the German government passed a new law on gender quotas. Since 2016, supervisory boards of stock market listed companies with more than 2,000 employees must comprise of at least $30 \%$ females. Moreover, other companies with co-determination duty have to impose quotas by themselves for their supervisory boards as well as boards of directors and their medium and upper management levels. One goal of this policy is to enhance the chances of females to obtain management positions.

${ }^{3}$ Hsieh et al. (2013) found that in the U.S. between 1960 and 2008, 15 to 20 percent of growth in aggregate output per worker may be explained by the improved allocation of talented black men, black women and white women.
} 
The literature on promotion rates offers a number of possible explanations for the often observed gender gap in promotions to top positions of firms (see Blau and deVaro (2007) as well as Smith et al. (2013) for surveys). The classical argument postulates that female applicants face lower chances because of tastebased discrimination, according to which females are discriminated simply because employers, customers or colleagues dislike to engage with females (Becker, 1957). Evidence for taste-based discrimination has been provided, for instance, by Baert et al. (2016) who run a randomized field experiment in Belgium and find that applications of females are less successful than those of men when the new job implies a promotion.

Schein (1973) and Schein and Mueller (1992) argue that employers, colleagues and possible applicants have stereotypic views about characteristics and attitudes of successful middle managers. Empirically, Schein (1973) finds such views about successful managers among males in the UK, the US and Germany. In Germany, such views are even prevalent among women themselves. The authors argue that stereotypic views build barriers which hinder women to access management positions.

Bjerk (2008) provides a model with asymmetric information on the abilities of workers which results in lower promotion rates of females to top positions. Differences in promotions may stem from different sources. If men have on average higher skills than women this will lead to statistical discrimination. Furthermore, differences in the probability of promotion come from less precise skill signals or from a lower frequency of skill signals. For instance, gender differences in communication styles or in networks could lead to a higher ability of men to assess the skills of male applicants than those of female applicants. ${ }^{4}$

Apart from (taste-based or statistical) discrimination or from a misperceived view about characteristics, there are a number of theoretical models that predict different

\footnotetext{
${ }^{4}$ Empirical evidence for gender segregation in job search networks on the labor market is found by Saygin et al. (2014). Dustmann et al. (2016) find support for the existence of segregation related to citizenship in job search networks.
} 
promotion rates for men and women based on rational supply behavior. For instance, Lazear and Rosen (1990) assume that females have the same distribution of labor market ability but a higher ability for household activities than men (Lazear and Rosen, 1973). It follows that women are more likely to leave the workforce reducing the overall returns from human capital investments on the labor market. This in turn leads to an under-investment in human capital and reduces the likelihood that women choose career jobs that require high initial human capital investments. ${ }^{5}$

Preferences of women may also explain their low representation in management positions. Females may choose not to work in high career jobs as these often require a high commitment including overtime hours (Bossler and Grunau, 2016). Moreover, the literature presents evidence that females are less inclined to take part in competitions (Niederle and Vesterlund, 2007). This may be even more pronounced in the presence of a glass ceiling, i.e. when promotion prospects for women are lower.

In this paper, we add to the literature by analyzing whether there is genuine state dependence in the number of female manager hires in German plants. ${ }^{6}$ That is, we analyze (at the establishment level) whether an increase in the current number of females among the newly hired managers leads to an increase in the future number of female manager hires. In contrast to previous studies on manager hires, we focus on managers at the middle and the upper level. We apply dynamic linear models taking unobserved heterogeneity and the endogeneity of lagged dependent variables into account. In additional specifications, we use dynamic tobit and dynamic linear models to analyze if the share of female manager hires in future is affected by the share of female manager hires in present. Using administrative data from the Integrated Employment Biographies of the IAB (1979-2010) on all workers liable to social security in Germany, we are able to control for establishment specific variables

\footnotetext{
${ }^{5}$ Booth et al. (2003) provide a theoretical framework which is consistent with that by Lazear and Rosen (1990) but also with sticky floor models, i.e. with models which predict a similar promotion rate for both sexes but lower wage growth for women after promotion.

${ }^{6}$ Genuine state dependence (GSD) refers to the fact that the current value of a variable is causally related to the value of the variable in the past, i.e. controlling for associations arising from heterogeneity, observed or unobserved. The greater the GSD in the case of female manager hires, the more favorable the introduction of female quotas. Conversely, spurious state dependence favors measures related to individual or firm characteristics (Heckman, 1981).
} 
which are often not available. For instance, we have information on the separation rates of female and male managers and we are able to distinguish between external hires of managers and internal promotions into management positions.

Referring to the literature, there are several reasons for state dependence in female manager hires. Taste-based discrimination or gender stereotype views could be reduced once women enter management positions. Similarly, firms hiring female managers may be more attractive for future female applicants increasing the female labor supply to these firms' managerial positions. Furthermore, female networks could become more important for the hiring process and enhance the ability in the firm to assess skills of females (Bjerk, 2008). The appearance of these mechanisms would be consistent with the conjecture discussed in the literature that women help women to get into management positions (Matsa and Miller, 2011; Kunze and Miller, 2014).

The paper proceeds as follows: Section 2 discusses the existing empirical literature. Section 3 presents the empirical specification. Section 4 describes the data and Section 5 presents the results. Section 6 concludes.

\section{Review of empirical literature}

There has been, to the best of our knowledge, no study investigating the impact of female representation among managers (including the middle management) on female manager hires. However, there is considerable evidence on related topics like the gender gap in promotion rates in general and the effect of female representation in firms on chances of females to reach a position in the board of these firms.

The empirical literature on the gender gap in promotion rates presents mixed results. Using panel data on full-time employed men and women, Booth et al. (2003) show that women leave the labor force more often than men, but the probability of promotion is similar when staying in the labor force (referring to promotions between all occupational levels). However, wage increases after promotion are higher for men than for women. By contrast, Blau and deVaro (2007) use the Multi-City Study of 
Urban Inequality (MCSUI) employer survey for the US and find that women have lower promotion rates than men but the same wage growth after promotion.

Kunze and Miller (2014) use a longitudinal employer-employee dataset of 4,000 private firms in Norway. Looking at white collar workers they identify promotions between seven different task levels ranging from unskilled and routine tasks up to high skill and leadership tasks. Moreover, they are able to analyze both, internal promotions and promotions that come along with job mobility. Overall, there is a considerable gender gap in promotions even after controlling for a large number of employer and employee characteristics as well as firm (and plant) fixed effects. Higher shares of female workers at the next highest rank are associated with a significantly smaller promotion gap. However, a larger number of females at the same rank leads to a smaller likelihood of a female promotion.

The studies discussed so far focus on a broad range of workers including all occupational levels. Another strand of the literature analyzes the chances of women to get into top positions of firms. For instance, Smith et al. (2013) use a linked employer-employee dataset of all Danish companies to investigate gender differences in promotion rates to $\mathrm{CEO}$ positions. They find that after controlling for a wide number of variables there remains a considerable gap. However, an important part of the gap in promotion rates can be explained by sorting of women into HR, R\&D, and IT departments where the chances for promotion are lower.

Instead of estimating models for the probability of promotion at the individual level, Farrell and Hersch (2005) use poisson models at the firm level for the number of women added to the corporate board. Their dataset consists of firms in the US included in the Fortune 500 and Service 500 lists. Investigating the link between the existing representation of women in a firm (or sector) and the share of women hired for leading positions, they find that the existing percentage of women on the board is negatively associated with the number of females added to the board. This may be explained by tokenism behavior, i.e. one woman on the board satisfies the needs for diversity (Parrotta and Smith, 2013). 
Parrotta and Smith (2013) also perform their analysis at the firm level and use the share of women on the board of directors as the dependent variable. They apply linear models including firm fixed effects to a panel of all Danish companies. Firms with a female chairman have significantly fewer female members on the board. Interestingly, when the share of females among CEOs and vice-presidents in a given sector or the share of women in the company is high, the share of women on the board elected by staff members increases, pointing to the importance of sector specific female labor supply. ${ }^{7,8}$

Whereas other studies focus either on promotions in general or on promotions to top positions of firms like positions in the board of directors or supervisory boards, we explicitly focus on hires into management positions which include the middle and the upper level. Because it interacts more with non-managerial employees, the middle management may be even more important than the management at the upper level when it comes to decisions about the wage setting or promotions in firms. This suggestion is supported for Germany by Hirsch (2013). He estimates wage regressions controlling for job fixed effects and shows that the gender wage gap in plants is significantly reduced when increasing the share of female managers at the second level. By contrast, the female share at the first level is less important (but still significant). Gagliarducci and Paserman (2015), however, use the same dataset and do not find any effect of the female share of managers at the top on different plant and worker outcomes. However, they ignore managers at the second level.

Hensvik (2014) uses Swedish data and also controls for individual and firm

\footnotetext{
${ }^{7}$ For Germany, there are some studies discussed below which examine the impact of female leaders on the gender wage gap and other worker outcomes. Yet, we are not aware of any paper that investigates the impact of female managers on hiring decisions or promotions.

${ }^{8}$ Some studies use high quality data from specific labor markets to investigate the effect of gender composition on the chances of women to get hired. Bednar and Gicheva (2014) analyze the effect of supervisors in US schools on the fraction of female coaches in different sport disciplines. While the supervisor fixed effects have a strong impact, the gender of the supervisor does not strongly predict the fraction of females. Bagues et al. (2015) use a randomized natural experiment in the hiring process of professors in Italy and Spain. Their results show that there is no effect and in some circumstances even a negative effect of females in scientific comitees on the sucess rates of female applicants.
} 
specific unobserved heterogeneity to estimate the impact of female managers at the middle and upper level. She finds that female managers do not have an effect on the gender wage gap but a considerable effect on the hiring decisions. Firms with a larger share of female managers recruit more female non-managerial high-wage workers. $^{9}$

In contrast to the previous studies, Bertrand et al. (2014) do not investigate the impact of the middle management but the impact of the board of directors on worker outcomes. They do not find significant spill-over effects on wages and career opportunities of women of the $30 \%$ quota for the board of directors in Norway (imposed since 2006). ${ }^{10}$

\section{Empirical specification}

\subsection{Number of female manager hires}

We estimate dynamic linear models for $f_{i t}$, the number of female hired managers in plant $i$ in period $t:^{11}$

$$
f_{i t}=\lambda_{1} f_{i t-1}+\lambda_{2} m_{i t-1}+\mathbf{x}_{i t} \boldsymbol{\chi}+c_{i}+v_{i t} \quad(i=1, \ldots, N ; t=2, \ldots, T) .
$$

$\lambda_{1}$ measures the effect of the lagged number of female manager hires on its current value, i.e. true state dependence. We assume that the number of female manager hires is affected by its first lagged value but not buy further lags. This assumption is supported by tests which show that in our regression sample $v_{i t}$ is not autocorrelated.

\footnotetext{
${ }^{9}$ Other studies pointing to an effect of female managers on outcomes of non-managers include Hultin and Szulkin (2003), Cohen and Huffman (2007), Cardoso and Winter-Ebmer (2007), Flabbi et al. (2014) and Lucifora and Vigani (2016). Aslund et al. (2014) find that in Sweden the probability of a new hire being a migrant is significantly increased when the manager has the same origin.

${ }^{10}$ Another strand of the literature deals with the impact of females in leading positions on firm and worker outcomes in general. For instance, Matsa and Miller (2013) establish that firms affected by the Norwegian quota undertook fewer workforce reductions and experienced increasing labor costs and employment levels as well as a reduction of the short-run corporate profitability. The results by Ahern and Dittmar (2012) point to negative effects of the Norwegian quota. The announcement of the law caused a significant drop in the stock price of firms.

${ }^{11}$ For ease of exposition, we ignore unbalancedness of the data in this section.
} 
$m_{i t-1}$ denotes the number of male hired managers in period $t-1$. It is important to control for the lagged number of male manager hires in order to assure that measured state dependence in $f_{i t}$ (captured by $\lambda_{1}$ ) is related to the theoretical channels discussed in the introduction and not to gender neutral state dependence in the number of hired managers. While gender neutral state dependence in the number of hired managers should lead to similar effects of both $f_{i t-1}$ and $m_{i t-1}$, state dependence solely related to gender should lead to a positive effect of $f_{i t-1}$ only. Taken together, $\lambda_{1}$ should be significantly larger than $\lambda_{2}$.

$\mathbf{x}$ is a vector including a constant and various explanatory variables. We control for the female share among managers in $t-1$ and the number of managers in total in $t-1$. We include the lagged values of these variables to avoid that they pick up effects of the number of hired female managers in $t-1 .{ }^{12}$ We additionally include sectoral affiliation dummies and the female share among non-managers as well as the share of highly qualified workers (to control for plant heterogeneity which is not captured by sectoral dummies), the year of foundation of the plant and dummy categories for plant size, region (Bundesland), urbanisation and the time period. $c_{i}$ denotes time-constant plant heterogeneity and $v_{i t}$ measures time-varying unobservables.

When estimating Equation (1) by OLS, i.e. not controlling for $c_{i}$, the correlation of $c_{i}$ with $f_{i t-1}$ leads to overestimation of state dependence (assuming positive state dependence). The $c_{i}$ can be swept out by taking first differences of Equation (1). However, correlation of $\Delta f_{i t-1}$ and $\Delta v_{i t}$ leads to a downward bias in the estimates of $\lambda_{1}$. Relatedly, elements of $\Delta m_{i t-1}$ and $\Delta \mathbf{x}$ which are not strictly exogenous are correlated with $\Delta v_{i t}$. Therefore, we instrument $\Delta f_{i t-1}, \Delta m_{i t-1}$ and $\Delta \mathbf{x}_{i t}$ with $f_{i t-2}, f_{i t-3}, m_{i t-2}, m_{i t-3}$ and with $\mathbf{x}_{i t-1}, \ldots, \mathbf{x}_{i 1}$ in a GMM framework as proposed by Arellano and Bond (1993). ${ }^{13}$ Assuming that $E\left[f_{i t-s} \Delta v_{i t}\right]=0$ and $E\left[m_{i t-s} \Delta v_{i t}\right]=0$

\footnotetext{
${ }^{12}$ Stock variables like the female share among managers are always measured at the beginning of the respective time period. The share of female managers in $t-1$ therefore predates the number of hired female managers in $t-1$.

${ }^{13}$ Additional instruments are available by using further lagged values back to $f_{i 1}$ and $m_{i 1}$. However, as discussed by Andersen and Sørensen (1996) and Roodman (2009), the coefficients of dynamic linear models as well as the tests of overidentifying restrictions may be sensitive to the number of instruments used. Therefore, we restrict the set of instruments to $f_{i t-2}, f_{i t-3}$ and $m_{i t-2}, m_{i t-3}$ (the number of instruments for $\Delta \mathbf{x}_{i t}$ are unrestricted). Specifications with more
} 
for $s \geq 2$ and that $E\left[x_{i t-s} \Delta v_{i t}\right]=0$ for $s \geq 1$, estimates of $\lambda_{1}$ are consistent. This requires no serial correlation of $v_{i t}$, which can be tested.

Arellano and Bover (1995) and Blundell and Bond (1998) proposed to use additional moment conditions where equation (1) is instrumented by lagged differences assuming that $E\left[\Delta f_{i t-1} c_{i}\right]=0$, and equivalently for the other instrumenting variables. ${ }^{14}$ If these moment conditions hold, the efficiency of the resulting system GMM estimator is greatly improved compared to the estimator by Arellano and Bond (1993). We will refer to this specification as Arellano-Bover specification throughout the paper.

We also run the specifications described above with the number of male hired managers as the dependent variable, where we expect $\lambda_{2}>\lambda_{1}$ if there is gender specific state dependence.

\subsection{Share of female manager hires}

\section{Linear models}

In additional specifications, we investigate state dependence in the share of female hired managers. We specify a dynamic linear model for $y_{i t}$, the female share of hired managers of plant $i$ in period $t$ :

$$
y_{i t}=\gamma_{1} y_{i t-1}+\gamma_{2} y_{i t-2}+\mathbf{x}_{i t} \boldsymbol{\beta}+a_{i}+e_{i t} \quad(i=1, \ldots, N ; t=3, \ldots, T) .
$$

We assume that the current share of females is affected by the share of females in periods $t-1$ and $t-2 .^{15} \mathrm{x}$ is a vector of control variables identical to those in Equation (1) except that we include the share of managers instead of the number of managers. $a_{i}$ captures unobserved time-constant plant heterogeneity, while $e_{i t}$

instruments led partly to unsatisfactory Hansen test-statistics, while the coefficient estimate of the lagged dependent variable remained largely unchanged.

${ }^{14}$ Analogous to the instruments for the differenced equation, we restrict the instruments for the levels equation to $\Delta f_{i t-1}, \Delta f_{i t-2}$ and $\Delta m_{i t-1}, \Delta m_{i t-2}$ (the number of instruments for $\mathbf{x}_{i t}$ are unrestricted).

${ }^{15}$ We also tested specifications with only one lagged dependent variable. However, the ArellanoBond-test indicated autocorrelation of second-order. 
denotes time-varying unobserved effects.

\section{Nonlinear models}

The linear model outlined above does not take into account that the female share in manager hires ranges between zero and one and that the share exhibits spikes at both ends of the interval. As a consequence, the coefficients obtained from a linear model may poorly approximate partial effects. For panel data with fractional dependent variables, Papke and Wooldridge (2008) propose a pooled fractional probit model. However, the presence of lagged dependent variables requires specifying the distribution of unobserved effects in a maximum likelihood framework which leads to inconsistent results in the fractional probit model (Papke and Wooldridge 2008, Wooldridge 2010, p. 629). We therefore follow Loudermilk (2007) and apply dynamic two-limit tobit models with random effects which are estimated with maximum likelihood.

We specify the latent dependent variable $y^{*}$ for firm $i$ in period $t$ as follows:

$$
y_{i t}^{*}=\omega_{1} y_{i t-1}+\omega_{2} y_{i t-2}+\mathbf{x}_{i t} \boldsymbol{\eta}+\nu_{i}+\varepsilon_{i t} \quad(i=1, \ldots, N ; t=3, \ldots, T) .
$$

The lagged values of the dependent variable in Equation (3) are necessarily correlated with the random effects $\nu_{i}$. While the correlation of the endogenous variables $y_{i 3}, \ldots, y_{i T}$ with $\nu_{i}$ is explicitly modelled when estimating Equation (3), correlation of $y_{i 1}$ and $y_{i 2}$ with $\nu_{i}$ is not controlled for which leads to the initial conditions problem (Heckman 1981). ${ }^{16}$ Heckman (1981) suggests to approximate the distribution of the initial values conditional on $\mathbf{x}$ and $\boldsymbol{\nu}$ with an additional equation and hence to model the correlation of the initial values and the random effects. A solution which is easier to implement is proposed by Wooldridge (2005). Here, the correlation of the initial values and the random effects is modeled by specifying the distribution

\footnotetext{
${ }^{16}$ We can only model the joint distribution of $y_{i 3}, \ldots, y_{i T}$ because the explanatory variables $y_{i t-1}, y_{i t-2}$ are not observed prior to $t=3$.
} 
of $\boldsymbol{\nu}$ conditional on $\mathbf{x}$ and the initial values $y_{i 1}, y_{i 2}$ :

$$
\nu_{i}=\kappa_{0}+\kappa_{1} y_{i 1}+\kappa_{2} y_{i 2}+\overline{\mathbf{x}}_{i} \boldsymbol{\tau}+\xi_{i}
$$

where $\overline{\mathbf{x}}_{i}=\frac{1}{T-2} \sum_{t=3}^{T} \mathbf{x}_{i t}{ }^{17}$ Hence, we can now substitute Equation (4) into Equation (3). $y_{i 1}, y_{i 2}$ and $\overline{\mathbf{x}}_{i}$ are simply added to the vector of explanatory variables. We assume that $\varepsilon_{i t}$ is strictly exogenous and follows a normal distribution with mean 0 and variance $\sigma_{\epsilon}^{2}{ }^{18}$ The resulting likelihood function for the dynamic two-limit Tobit model has the following form:

$L=\sum_{n=1}^{N} \int \Phi\left\{\frac{-\mathbf{z}_{i t} \boldsymbol{\iota}}{\sigma_{\varepsilon}}\right\}^{\left(1\left[y_{i t}=0\right]\right)} \phi\left\{\frac{y_{i t}-\mathbf{z}_{i t} \boldsymbol{\iota}}{\sigma_{\varepsilon}}\right\}^{\left(1\left[0<y_{i t}<1\right]\right)} \Phi\left\{\frac{\mathbf{z}_{i t} \boldsymbol{\iota}-1}{\sigma_{\varepsilon}}\right\}^{\left(1\left[y_{i t}=1\right]\right)} \frac{1}{\xi} \phi\left\{\frac{\xi}{\sigma_{\xi}}\right\} d \xi$

where $\mathbf{z}_{i t} \boldsymbol{\iota}=\omega_{1} y_{i t-1}+\omega_{2} y_{i t-2}+\mathbf{x}_{i t} \boldsymbol{\eta}+\kappa_{1} y_{i 1}+\kappa_{2} y_{i 2}+\overline{\mathbf{x}}_{i} \boldsymbol{\tau}+\xi_{i} ; \Phi$ and $\phi$ denote the cdf and pdf of the standard normal distribution, respectively. Average partial effects (APE) are calculated with numerical methods using Stata 14.

\section{Data construction and descriptive statistics}

\subsection{Data construction}

Our analysis is based on the Integrated Employment Biographies (IEB) of the Institute for Employment Research (IAB). It is the major administrative data source for employment information in Germany which is retrieved from mandatory employment reports to the Federal Employment Agency for each regular employee in Germany since 1975. Each employer located in Germany is required to report

\footnotetext{
${ }^{17}$ Wooldridge (2005) proposes to include $x_{i 3}, \ldots, x_{i T}$ instead of $\overline{\mathbf{x}}_{i}$. However, Rabe-Hesketh and Skrondal (2013) show in a simulation study that including the mean values of $\mathbf{x}$ produces similar results. This procedure is attractive because it can also be applied on unbalanced datasets.

${ }^{18}$ Modelling unobserved heterogeneity as the sum of time-constant random effects $\boldsymbol{\xi}$ and strictly exogenous contemporary time shocks $\varepsilon$ rules out firm specific time trends in manager hires. Prowse (2013) estimates a dynamic multinomial logit model with random effects and relaxes the assumption of time-constant individual effects by modelling autocorrelation in the time shocks. However, the underlying assumptions concerning the structure of autocorrelation are quite restrictive. Moreover, the female share of hires for management positions (which we use as the dependent variable) should be less affected by time trends than the share of females in the stock of management positions.
} 
detailed information about each employee at least once a year. This information is of high precision as it is the basis for social security contributions and benefit eligibility. The data includes each employment spell with a start date and an end date. It covers information on wages and occupations, but also some demographic characteristics such as gender, which is the focus of this paper. A more comprehensive description of the Integrated Employment Biographies can be found in Oberschachtsiek et al. (2009).

We started by selecting all employees in the IEB who are employed on June 30th of a respective year. We then restricted the sample to establishments with a median employment of at least 50 in order to reduce attrition due to zero manager hires in our econometric specifications for the share of females among manager hires. ${ }^{19}$ The data includes unique individual as well as establishment identifiers which allows tracking both individuals and establishments over time. By the combination of both we can distinguish between newly hired individuals and incumbent workers. Also vital for our research question, managers can be identified from a 3-digit occupational code. Employees were categorized as managers according to an aggregation proposed by Blossfeld (1987).

Next, we aggregated the individual information to obtain the number of employees, managers, manager hires, separations and promotions of managers - each differentiated by gender - as well as the total number of hires and the number of high qualified employees to the establishment level, which is the unit of observation for our analysis. Since most of the establishments do not replace their management year by year, for a considerable number of plants we do not observe manager hires each year. We therefore aggregated the establishment level observations into fouryear periods, which is approximately equal to the median tenure of a manager in the observed sample (4.02 years). This leads to an establishment panel dataset with eight waves: $t_{1}=1979-1982, t_{2}=1983-1986, \ldots, t_{8}=2007-2010 .{ }^{20}$ The number

\footnotetext{
${ }^{19}$ The restriction according to the median (instead of the current employment) ensures that all establishments in our sample are tracked from the very beginning of their appearance until they disappear from the data.

${ }^{20}$ We did not include 1975 - 1978 since without information in 1974 we could not calculate the
} 
of manager hires and the other flow variables are cumulated over such four year periods. All stock variables including establishment size, the share of high qualified employees, and the share of females in non-managerial occupations are retrieved from the first year of these four year periods. This ensures that covariates are rather pre-determined and are not endogenously determined within these four year time horizons. See figure 1 for an illustration of the measurement of explanatory and dependent variables.

We restricted our regression sample to establishments located in Western Germany allowing us to construct a time-series starting prior to the German reunification in 1990. Furthermore, this leads to a more homogeneous sample; in 2013, for example, the labor market participation of women was still five percentage points higher in Eastern than in Western Germany (Schnabel, 2016). Further, after constructing a time-persistent industry identifier using the procedure by Eberle et al. (2011) we excluded the public sector. We also dropped all establishments for which we do not observe any managers, which are in most cases small single unit establishments. ${ }^{21}$ Finally, we excluded all establishments in which the fraction of managers exceeds 50 percent of the work force, most of which were operating in consulting.

In our regression analysis, we investigate state dependence in the number of females among all manager hires and, alternatively, state dependence in the share of female manager hires. The sample size differs for these two outcome variables. As the share of female manager hires cannot be calculated for establishments which did not hire any manager in the respective period, this outcome is analysed using a sample comprising of observations with a positive number of manager hires (Regression Sample 2). By contrast, the number of females among all manager hires takes on a value of zero if no female manager is hired, irrespective of whether or not a manager is hired in the respective time period (Regression Sample 1).

number of hires between 30th of June 1974 and 30th of June 1975.

${ }^{21}$ Managers of small single unit establishments are often self-employed and are therefore not included in our data. 
This sample includes plants which are observed in at least three consecutive time periods which is (according to Equation (1) with one lagged dependent variable in first differences) the minimal requirement to be included in the Arellano-Bond specification. Regression Sample 1 contains 148,131 observations from 33,237 plants, pooled over the seven periods $t_{2}=1983-1986, \ldots, t_{8}=2007-2010 .^{22}$

In Regression Sample 2, each plant has to be observed in at least four consecutive time periods which is (according to Equation (2) with two lagged dependent variables in first differences) the minimal requirement to be included in the Arellano-Bond specification. Regression Sample 2 contains 38,077 observations from 10,786 plants, pooled over the six periods $t_{3}=1987-1990, \ldots, t_{8}=2007-2010 .^{23}$

\subsection{Descriptive statistics}

Table 1 displays sample averages of Regression Sample 1 which we use for our analysis with the number of female manager hires as the dependent variable. The penultimate row of the table shows that in four out of five plant-year observations female manager hires do not occur. In 17.6 percent of the cases, 1-4 female manager hires are observed and for 1.8 percent of observations female manager hires range between five and nine. For only 1.1 percent of all observations, female manager hires exceed nine. Note that the mean of female manager hires in the sample $(0.8)$ is about four times smaller than the average of male manager hires (3.1). Looking at (internal) promotions, the (average) female to male ratio is one to five, such that the gender gap is more pronounced for promotions than for hires. At the same time, the mean of female manager separations (0.8) is more than five times smaller than the average of male manager separations (4.3). The female share of managers is positively correlated with the number of female manager hires. However, note that this is not due to the definition of both variables, since the share measures the stock at the beginning of a four year window, while the hires measure the flow during the respective window.

\footnotetext{
${ }^{22}$ The first period is not counted because it is used to construct $f_{i t-1}$ and $m_{i t-1}$.

${ }^{23}$ The first two periods are not counted because they are used to construct $y_{i t-1}$ and $y_{i t-2}$.
} 
The average establishment size measured in terms of number of employees is 299.1 and not surprisingly the number of female manager hires increases with establishment size. While plant size of those plants with zero female manager hires is below average (226), the average plant size of plants with 10-19 female manager hires is 1404.7. The mean of the number of managers is about eight in the whole sample and ranges between about 4.4 for those with zero female manager hires and about 490 for those plants with more than 50 female manager hires. The average number of female managers in the sample (1.0) is considerably lower than the average number of male managers (about seven).

The female share among non-managers is on average 37.3 percent and thus considerably higher than the share of females within managers (11.1 percent) implying a glass ceiling phenomenon also in Germany. The female share among non-managers is also relatively high for those observations which do not hire any female managers (35.5 percent) but larger for those who hire female managers. While the share of qualified employees is clearly strongly increasing with the number of female hired managers, the latter is unrelated to the year of plant foundation.

Most of the plants in our sample belong to metropolitan areas (36.4 percent) and metropolitan surroundings (43.9 percent). There is a positive relationship between metropolitan area and female manager hires. However, this is (at least to a large extent) driven by establishment size. The mean values of the period dummy variables imply that in our unbalanced sample we observe slightly more observations at the beginning of the observation period (where the highest share corresponds to the period 1987-1990). 


\section{Results}

\subsection{Linear Models for the number of female manager hires}

Table 2 shows the results from dynamic linear models for the number of female manager hires as the dependent variable. ${ }^{24}$ Specification (1) is a simple dynamic linear model where no control variables except the lagged number of male manager hires and time dummies are included.

The coeffcient of the lagged number of female manager hires is almost equal to one and highly significant whereas the lagged number of males is insignificant. That is, the number of female manager hires is only sensitive to the number of female manager hires, but not to the number of male manager hires in the past. The measured effect is of considerable size. Consider a plant A which hires one female manager in period $t$ and zero male managers whereas plant B hires one male manager in period $t$. In period $t+1$ plant $\mathrm{A}$ would hire one female manager again whereas plant B would not hire female managers at all (due to state dependence).

Model (2) adds control variables. We include variables like the female share among non-managers and the share of highly qualified workers to control for plant heterogeneity which may not be completely captured by the broad sector dummies in our model. For instance, plants with a high share of female employees may belong to sectors with a high female labor supply. Similarly, the number of managers in a plant and the share of highly qualified employees may capture heterogeneity across plants which is not controlled for by the sector dummies and which might be associated with the labor supply of women to manager positions. It turns out that the number of female manager hires is strongly related to the share of highly qualified workers. Large plants hire on average more female managers than small plants, although the effect is nonlinear and the estimated coefficients of the size dummies are imprecisely estimated.

\footnotetext{
${ }^{24}$ The results (available upon request) obtained for the smaller subsample without plants with zero managers (i.e. for Regression Sample 2) are qualitatively similar to those reported in this subsection.
} 
In model (2) the coefficient for the lagged dependent variable is again about one and highly significant. In contrast, the female share among managers in period $t-1$ does not have an effect on the number of female hired managers in period $t$. That is, the number of female managers who have entered the plant in the last four-year period have a large effect on the number of female manager hires in the current four-year period, while the share of female managers in the plant at the beginning of the most recent four year period does not play a role (see section 4.1 and figure 1 for the measurement of explanatory and dependent variables within the four year periods).

This result implies that increasing the number of female manager hires has an effect already in the short to medium run. This finding may be motivated with the job durations of managers in our sample. Only 47.92 percent of those managers who have been working in a plant in the year 1991 are still working in the same plant as managers in the year 1995. After six years, 33.37 percent stay in their job and after eight years the survival rate is only 28.18 percent. ${ }^{25}$ Clearly, this makes it less likely that the stock of female managers in 1991 has an effect on the hirings in the 1995-1998 period.

Model (3) is a dynamic linear model estimated with system GMM using the specification proposed by Arellano and Bover (1995) and Blundell and Bond (1998). Not using control variables other than time dummies, the coefficients for the lagged number of female hired managers is 0.950 . The coefficient for the lagged male number of hired managers remains small and insignificant. Adding control variables to the Arellano-Bover specification (model 4) leads to a slight decrease of the coefficient for the lagged number of female hired managers to 0.909. The obtained state dependence is still economically (and statistically) highly significant. An increase of the number of female hired managers in $t$ by ten leads to an increase of female hired managers in

\footnotetext{
${ }^{25}$ These numbers are consistent with job durations published in Boockmann and Steffes (2005, p. 116). For Western Germany, they find that survival rates of workers are clearly below 50 percent after four years. Note that in our case job durations of managers employed at a plant in period $t-1$ are left-censored while Boockmann and Steffes (2010) look at an inflow sample of all workers.
} 
$t+1$ by about nine. Again, there is no effect of the number of male hired managers. ${ }^{26}$

Model (5) applies the specification proposed by Arellano and Bond (1993) where the dynamic linear model is estimated in first differences and lagged levels of the explanatory variables are used as instruments. Using this specification, the coefficient for the lagged number of female hired managers reduces to 0.470 and remains highly significant.

We prefer model (4) over model (5) for two reasons. First, under standard conditions the OLS estimator overestimates the effect of the lagged dependent variable whereas the fixed effects model underestimates it. In our case, the effect estimated by pooled OLS (model 1) is one and the effect estimated by fixed effects is 0.674 (model 6), such that the true coefficient should be bounded by these two values. This points to the credibility of the Arellano-Bover specification. Second, Blundell and Bond (1998) have shown that the estimate for the coefficient of the lagged dependent variable using the Arellano-Bond specification is considerably biased downwards when its true value is large and when the number of time periods is moderately small while Arellano-Bover performs well.

The models presented in Table 3 enhance baseline model (4) by taking other sources of employee turnover in the establishment into account which may be related to the process of hiring managers. For instance, the number of female hired managers may be related to the separation rate of female managers. Model (7) therefore additionally includes variables for the number of female and male managers separated in period $t-1$. While the number of male separated managers in $t-1$ does not have an effect on the number of female hired managers, the coefficient for the number of female separated managers in $t-1$ is negative and significant. This result is consistent with the positive effect of lagged female manager hires as both findings suggest state dependence of female representation among managers. The coefficient of the lagged number of female manager hires increases slightly.

Instead of including both - the number of hired and separated managers in

\footnotetext{
${ }^{26}$ The Hansen test statistic for model (4) suggests the validity of the used instruments. Also, the Arellano-Bond test is satisfactory since there is no evidence second order autocorrelation.
} 
$t-1$, model (8) controls for the difference between the number of hired managers and the number of separated managers in $t-1$ for women and men. An increase in the difference between the number of female hired managers in $t-1$ and the number of female separated managers in $t-1$ by one leads to a significant increase in the number of female hired managers in $t$ by $0.543 .{ }^{27}$ The respective variable for men has an effect of 0.090 which is significant at the 10 percent level. However, the effect of females is significantly larger (at the 1 percent level) than the effect of males.

Model (9) expands model (4) by controlling for internal promotions into management positions. While the coefficient for the lagged number of female promotions is significant, the effect (0.099) is relatively small compared to the impact of past female manager hires (0.956), showing that female hires from other plants are more important for the chances of external applicants than internal promotions.

Table 4 reports models that analyze internal promotions in more detail. Model (10) uses the sum of the number of females promoted into management positions and the number of female managers externally hired as the dependent variable. The measured effects are in line with previous results. The coefficient of the number of female promoted and hired managers in $t-1$ is large (0.797) and significant while the effect of the respective variable for males is 0 .

In specifications (11) and (12), the dependent variable comprises the number of promoted female managers. It can be observed that neither the lagged number of promoted managers (whether female or male) nor the lagged number of hired managers (whether female or male) have an influence on the current number of female promotions into manager positions. Furthermore, the coefficients for the share of female managers in $t-1$ are not significant. The result may be explained with the possibility of male managers to screen candidates for promotions while they are working at lower positions in the establishment. Whereas the significant effect of the lagged number of female manager hires on the current number of female manager hires may be driven by a lower ability of male managers to assess skills of female

\footnotetext{
${ }^{27}$ Not surprisingly, this number lies between the estimates for female hired managers, $t-1$ and (minus) female separated managers, $t-1$ of the less restrictive model (7).
} 
applicants (Bjerk, 2008), this mechanism may be of less importance for internal promotions when managers get information on worker's skills during a screening period before promotion. Our result are in line with those of Bossler and Grunau (2016). They analyze the determinants of external and internal promotions into management positions and find that the disadvantages of women are lower with respect to internal promotions compared to external promotions to management positions in other plants.

Table 5 reports analogous regressions to those of Table 2, but now with the number of male hired managers as the dependent variable. Clearly, there is also state dependence in the number of male hired managers. The point estimates are somewhat smaller than in the respective regressions for female manager hires, but the confidence intervals overlap. The Arellano-Bover specifications (15) and (16), for example, imply that increasing the number of male manager hires in $t-1$ by ten increases ceteris paribus the number of male manager hires in $t$ by about seven. Again, the estimate obtained using the Arellano-Bond specification (model 17) leads to a coefficient which is considerably smaller and also below the Fixed Effects estimate, pointing towards a downward bias of the Arellano-Bond estimate.

To summarize, the models for the number of female manager hires consistently show that there is true state dependence, i.e. increasing the number of female manager hires in present leads to more female manager hires in the future. Similarly, there is true state dependence in the number of male hired managers, but the effect is weaker. Both results show that the process of hiring managers is not gender neutral.

\subsection{Robustness checks}

One might speculate that the parameter estimates for the lagged number of female hired managers capture rather firm specific time trends in the female workforce than true state dependence. First, we argue that the hires of women for management positions (i.e. our dependent variable) should be less affected by time trends than the actual number of females in the stock of management positions. Second, we offer 
indirect evidence on this issue by re-running our preferred specification (i.e. ArellanoBover estimations) with industry specific time trends modeled via interaction terms between the period dummies and 89 industry dummies. Compared to specification (4), the obtained coefficient for the lagged number of female hired managers changed only slightly (from 0.909 to 0.922 ). Again, when adding interactions of the industry dummies with a continuous variable, i.e. assuming linear time trends, the coefficient of interest barely changes (from 0.909 to 0.918 ). These results indicate that our findings of state dependence in establishments' hiring behavior of female managers are not confounded by time trends in female manager hires, assuming that these do not differ within (narrowly defined) sectors.

We also investigated whether state dependence in the hiring of female managers changes over time. This is interesting per se. In addition, due to institutional reasons, one might expect to find a larger state dependence in the second half of the sample when the issue of increasing the share of women in leadership positions has become more prominent in Germany. However, when we split the sample into two time windows, estimates for state dependence using the specification of model (4) do not change considerably.

In additional robustness checks, we expand models (4) and (16) by including the lagged female hired managers and the lagged male hired managers as spline functions, i.e. we allow for piecewise linearity in these variables in order to check if the effects of the lagged dependent variables are driven by firms with extreme values in the lagged number of female or male manager hires. However, it turns out that the lagged number of female (male) manager hires has an effect on the number of female (male) manager hires in present across all splines. If fact, we cannot reject the hypothesis that state dependence is linear. ${ }^{28}$

\footnotetext{
${ }^{28}$ Results for the spline regressions as well as for the sample split into the two time windows are available upon request.
} 


\subsection{Female share of manager hires}

\section{Linear models for the female share of manager hires}

Table 6 reports the linear regression results with the female share in manager hires as the dependent variable. Note that compared to the specifications (1)-(18), the number of plants is considerably lower $(33,237)$ since the dependent variable is not defined for plant-year observations with zero manager hires. Specification (19) is a simple OLS model including the first two lags of the dependent variable and time dummies. The coefficient of the first lag of the dependent variable shows that an increase of the share of female manager hires by ten percentage points is on average associated with an increase of the share in the next period by 2.99 percentage points. The second lag of the dependent variable points to an additional direct effect on the next but one period by 2.26 percentage points (not controlling for observed and unobserved variables).

The coefficients of model (19) point to a strong relationship between the past and the current share of female manager hires. For example, consider two plants where in period $t$ plant $\mathrm{A}$ hires a female manager and plant $\mathrm{B}$ hires a male manager. If both hire one manager again in period $t+1, \mathrm{~A}$ has (due to state dependence) a 29.9 percentage points larger probability to hire a female manager than B. In case both hire also one manager in period $t+2$, then we predict (after period $t$ ) for period $t+2$ that $\mathrm{A}$ has due to state dependence a 31.5 percentage points larger probability to hire a female manager. ${ }^{29}$

Specification (20) additionally includes various control variables, which reduces the coefficients of the lagged dependent variables somewhat. While the the R-squared increases only from 0.189 to 0.228 , the coefficients of the control variables are significant. Increasing the share of female managers in $t-2$ by ten percentage points leads to an increase in the share of female hired managers in $t$ by 1.39 percentage points. In addition, a higher female share among non-managers is associated with a

\footnotetext{
${ }^{29}$ This decomposes into an effect by 8.9 percentage points $\left(0.299^{*} .299\right)$ from period $t+1$ and an effect of 22.6 percentage points from period $t$ ).
} 
higher female share in manager hires. These results are in contrast to the specification with the number of female or male manager hires as the dependent variable where the respective coefficients were insignificant. The share of females within managers rises with plant size. Note that by controlling for the share of managers, we take into account that plants without managers are not included in our sample.

Specifications (21) and (22) contain the Arellano-Bover estimates with and without time-varying control variables. The coefficients of the lagged dependent variables reduce again, but state dependence is still of considerable size and statistically significant. An increase of the share of female manager hires by ten percentage points is associated with an increase of the share in the next period by about 1.86 percentage points and by about 1.05 percentage points in the next but one period. The effects of other control variables remain significant, apart from the plant size dummies, where the coefficients are estimated very imprecisely. Notable, the effect of the share of managers in $t-2$ is now estimated to be positive and significant. The Hansen statistic of our preferred specification (22) does not reject the null hypothesis that the instruments are exogenous. ${ }^{30}$ Further, the Arellano-Bond test statistic is consistent with no second order autocorrelation in the error term. ${ }^{31}$ Reassuringly, the estimates of the lagged dependent variables lie between those of the fixed effects and the OLS coefficient. Contrarily to Table 2, the Arellano-Bond and Arellano-Bover estimates are now almost identical. ${ }^{32}$

\footnotetext{
${ }^{30}$ In the reported specification, plant size dummies were not included as instruments, because if they were included the Hansen test indicated that some instruments might be endogenous. Nevertheless, whether we used these variables as instruments or not had no effect on the coefficient estimates of the lagged dependent variables. Note that the period dummies were treated as strictly exogenous.

${ }^{31}$ Note that estimating model (22) with only one lag of the dependent variable instead of two goes along with second order autocorrelation (results are available upon request).

${ }^{32}$ The actual number of female hired managers shows a higher persistence than the share of females within hired managers. Hence, for the former the lagged values may be poor instruments for the first differenced variables which probably led to a downward bias of the Arellano-Bond estimator for these specifications and very likely also explains why the reported Arellano-Bond estimates were lower than the Fixed Effects Estimates in Tables 2 and 5.
} 


\section{Nonlinear models for the female share of manager hires}

Table 7 shows average partial effects (APE) of dynamic tobit models. The APE obtained from the dynamic tobit model without covariates and not controlling for time-constant random effects (specification 25) is 0.247 for the female share in manager hires and 0.179 for the second lag. This is slightly lower than those in the comparable linear model (specification 19). When adding control variables, the APEs are again reduced, but remain economically and statistically significant. Specification (27) is a dynamic tobit model with random effects including the first two initial values of the dependent variable to take into account the initial conditions problem. The average partial effects of both initial values are positive and highly significant — implying that the initial values are correlated with time-constant unobserved variables and that not controlling for the initial conditions leads to an upward bias of the coefficients of the lagged dependent variables. Consequently, the APEs fall considerably compared to the APEs of (25) and (26). The APE of the first lag of the dependent variable is 0.060 while the APE of the second lag is $0.032 . \sigma_{\xi}$ is also significant meaning that not controlling for time-constant random effects would lead to biased estimates (Wooldridge, 2010).

Specification (28) includes additionally time-constant and time-varying control variables as well as plant averages of the time-varying variables. The APEs of the control variables do not change qualitatively compared to those estimated in model (20) apart from the average partial effect of Female share among managers, $t-2$ which turns from statistically significant positive to negative. ${ }^{33}$ The main variables of interest, namely the lagged variables of the female share in hired managers are hardly affected by the inclusion of the time-varying control variables and of their plantaverages. To summarize, the non-linear models lead to somewhat smaller estimates of the lagged dependent variables than the linear specifications. However, they still point to true state dependence in the female share of hired managers.

\footnotetext{
${ }^{33}$ Note, however, that for this variable most probably the assumption of strict exogeneity does not hold. We include it in the regression to be consistent with the Arellano-Bover models which do not require the assumption of strict exogeneity.
} 
The tobit model is particularly sensitive with respect to violations of distributional assumptions (e. g. Cameron and Trivedi 2005, p. 538). To test the robustness of our results, we estimate a dynamic ordered probit model with random effects where the dependent variable represents six categories for the female share of hired managers: $y=0,0<y<0.25,0.25 \leq y<0.5,0.5 \leq y<0.75,0.75 \leq y<1$, $y=1$. Also for the dynamic ordered probit model, the problem of initial conditions is addressed by applying the method of Wooldridge (2005). In this case, initial values of the six categories (again, both for $t=1$ and $t=2$ ) are included. We find that state dependence is present for the whole distribution of the lagged dependent variables. Moreover, the ordered probit model yields the same effects as a dynamic tobit model where $y_{t-1}$ and $y_{t-2}$ are both split into the six categories listed above. ${ }^{34}$ This is in favor of the validity of the assumptions of normality and homoskedasticity. ${ }^{35}$

\section{Conclusions}

This study analyzes whether the number of female manager hires depends on the existing gender composition of managers in a plant. In contrast to previous studies on manager hires, we focus on managers at the middle and the upper level. Applying dynamic linear models controlling for unobserved heterogeneity and the endogeneity of lagged dependent variables to administrative data on all German establishments, we find that there is state dependence in the number of female manager hires. That is, an increase in the current number of female manager hires leads to an increase in the future number of female manager hires. Similarly, the number of male manager hires in the future is larger when more male managers are hired in the present. Furthermore, we show that manager hires in the most recent four year period have larger effects than those managers who have been in the plant before. Hence, plants which aim for enhanced gender related diversity should experience

\footnotetext{
${ }^{34}$ Results for both models, the dynamic ordered probit and the dynamic tobit with the lagged dependent variable split into categories are available upon request.

${ }^{35}$ We refer to Ruud (1984) who points out that under normality and homoskedasticity the tobit and the probit model should yield similar results for $P(y>0)$ while results should differ when the distributional assumptions are violated.
} 
an effect of increasing the number of female manager hires already in the short or medium run.

The finding of state dependence in female manger hires is very robust with respect to various alterations. For instance, the result is confirmed by dynamic linear models and dynamic tobit models for the share of female manager hires. We also used different sets of instrumental variables in the GMM regressions which led to the same conclusion. Moreover, state dependence is still present after the inclusion of sector specific time trends and when dividing the sample into two time windows. This points against the conjecture that the lagged dependent variables measure firm specific trends instead of true state dependence.

Our findings suggest that hiring managers is not gender neutral and that the chances of women to reach management positions are better if the firm has hired female managers in the past. This is consistent with the conjecture that women are helping women to get into management positions. It is left for future research to determine which economic mechanisms (reduction in stereotypes or in taste-based discrimination, greater importance of female networks, labour supply effects) are mainly responsible for this finding. While the result that women help women might not be surprising at first sight, the literature has shown - though for different contexts - that this is not unambiguously the case (Bagues et al., 2015; Farrell and Hersch, 2005).

Since 2016, German stock market listed companies with more than 2,000 employees must fill vacant positions in supervisory boards with a female person until a quota of $30 \%$ is reached. Assuming our findings are also valid for this particular subgroup of firms and top managers, we expect that the new law improves the chances of women entering the supervisory board in these firms even beyond the $30 \%$ quota. It will be interesting to investigate this implication in the future. 


\section{References}

Ahern, K. and Dittmar, A. (2012), 'The changing of the boards: The impact on firm valuation of mandated female board representation', Quarterly Journal of Economics 127(1), 137-197.

Andersen, T. G. and Sørensen, B. E. (1996), 'GMM estimation of a stochastic volatility model: A Monte Carlo Study', Journal of Business $\&$ Economics Statistics 14(3), 328-352.

Arellano, M. and Bond, S. (1993), 'Some tests of specification for panel data: Monte Carlo evidence and an application to employment equations', Review of Economic Studies 58, 227-297.

Arellano, M. and Bover, O. (1995), 'Another look at the instrumental variable estimation of error-compoments models', Journal of Econometrics 68, 29-51.

Aslund, O., Hensvik, L. and Skans, O. N. (2014), 'Seeking simsimilar: How immigrants and natives manage in the labor market', Journal of Labor Economics 32, 405-441.

Baert, S., de Pauw, A.-S. and Deschacht, N. (2016), 'Do employer preferences contribute to sticky floors?', Industrial and Labor Relations Review 69, 714736.

Bagues, M., Sylos-Labini, M. and Zinovyeva, N. (2015), Does the gender composition of scientific committees matter?, IZA Discussion Paper No. 9199, Institute for the Study of Labor, Bonn.

Becker, G. (1957), The economics of discrimination, Chicago Press.

Bednar, S. and Gicheva, D. (2014), 'Are female supervisors more female-friendly?', American Economic Review: Papers and Proceedings 5, 370-375. 
Bertrand, M., Black, S. E., Jensen, S. and Lleras-Muney, A. (2014), Breaking the glass ceiling? The effect of board quotas on female labor market outcomes in Norway, IZA Discussion Paper No. 8266, Institute for the Study of Labor, Bonn.

Bjerk, D. (2008), 'Glass ceilings or sticky floors? statistical discrimination in a dynamic model of hiring and promotion', The Economic Journal 118, 961Ü982.

Blau, F. D. and deVaro, J. (2007), 'New evidence on gender differences in promotion rates: An empirical analysis of a sample of new hires', Industrial Relations 46, 511-550.

Blossfeld, H.-P. (1987), 'Labor-market entry and the sexual segregation of careers in the federal republic of germany', American Journal of Sociology pp. 89-118.

Blundell, R. and Bond, S. (1998), 'Initial conditions and moment restrictions in dynamic panel data models', Journal of Econometrics 87, 115-143.

Boockmann, B. and Steffes, S. (2010), 'Workers, firms, or institutions: What determines job duration for male employees in Germany?', Industrial and Labor Relations Review 64, 109-127.

Booth, A. L., Francesconi, M. and Frank, J. (2003), 'A sticky floors model of promotion, pay, and gender', European Economic Review 47, 295 Ü322.

Bossler, M. and Grunau, P. (2016), 'Asymmetric information in external versus internal promotions', IAB-Discussion Paper, 11/2016, Nürnberg .

Cameron, A. C. and Trivedi, P. K. (2005), Microeconometrics: Methods and Applications, Cambridge University Press, Cambridge.

Cardoso, A. R. and Winter-Ebmer, R. (2007), 'Female-led firms and gender wage policies', Industrial and Labor Relations Review 64, 143-163.

Cohen, P. and Huffman, M. L. (2007), 'Working for the woman? Female managers and the gender wage gap', American Sociological Review 72, 681-704. 
Dustmann, C., Glitz, A., Schönberg, U. and Brücker, H. (2016), 'Referral-based job search networks', Review of Economic Studies 83, 514-546.

Eberle, J., Jacobebbinghaus, P., Ludsteck, J. and Witter, J. (2011), Generation of time-consistent industry codes in the face of classification changes - Simple heuristic based on the Establishment History Panel (BHP), FDZ Datenreport 05/20011, Research Data Centre (FDZ) of the Federal Employment Service and the Institute for Employment Research, Nürnberg.

Farrell, K. A. and Hersch, P. L. (2005), 'Additions to corporate boards: The effect of gender', Journal of Corporate Finance 11, 85-106.

FidAR (2016), Women-on-Board-Index, Report, FidAR. Frauen in die Aufsichtsräte e. V.

Flabbi, L., Macis, M., Moro, M. and Schivardi, F. (2014), Do female executives make a difference? The impact of female leadership on gender gaps and firm performance, CEPR Discussion Paper No. 10228.

Gagliarducci, S. and Paserman, D. (2015), 'The effect of female leadership on establishment and employee outcomes: Evidence from linked employer-employee data', Research in Labor Economics 41, 341-372.

Grant Thornton (2015), Women in business: the path to leadership, Grant Thornton International Business Report 2015.

Heckman, J. J. (1981), The incidental parameters problem and the problem of initial conditions in estimating a discrete time-discrete data stochastic process, in C. F. Manski and D. McFadden, eds, 'Structural analysis of discrete data with econometric applictions', The MIT Press, Cambridge, pp. 179-195.

Hensvik, L. (2014), 'Manager impartiality: Worker-firm matching and the gender wage Gap', Industrial and Labor Relations Review 67, 395-421. 
Hirsch, B. (2013), 'The impact of female managers on the gender pay gap: Evidence from linked employer-employee data for germany', Economics Letters 119(3), 348-350.

Hsieh, C.-T., Hurst, E., Jones, C. I. and Klenow, P. J. (2013), The Allocation of Talent and U.S. Economic Growth, NBER working paper No. 18693.

Hultin, M. and Szulkin, R. (2003), 'Mechanisms of inequality, unequal asccess to organisational power and the gender wage gap', European Sociological Review 19, 143-159.

Kosteas, V. D. (2011), 'Job satisfaction and promotions', Industrial Relations: A Journal of Economy and Society 50(1), 174-194.

Kunze, A. and Miller, A. R. (2014), Women helping women? Evidence from private sector data on workplace hierarchies, IZA Discussion Paper No. 8725, Institute for the Study of Labor, Bonn.

Lazear, E. P. and Rosen, S. (1973), 'The effect of children on the housewife's value of time', Journal of Political Economy 81, S168-S199.

Lazear, E. P. and Rosen, S. (1990), 'Male-female wage differentials in job ladders', Journal of Labor Economics 8(1), 106-123.

Lima, F. and Pereira, P. (2003), 'Careers and wages within large firms: evidence from a matched employer-employee data set', International Journal of Manpower 24(7), 812-835.

Loudermilk, M. S. (2007), 'Estimation of fractional dependent variables in dynamic panel data models with an application to firm dividend policy', Journal of Business and Economics Statistics 25, 462-472.

Lucifora, C. and Vigani, D. (2016), What if your boss is a woman? Work organization, work-life balance and gender discrimination at the workplace, IZA Discussion Paper No. 9737, Institute for the Study of Labor, Bonn. 
Matsa, D. A. and Miller, A. R. (2011), 'Chipping away at the glass ceiling: Gender spillovers in corporate leadership', American Economic Assiociation Papers and Proceedings 101, 635-639.

Matsa, D. A. and Miller, A. R. (2013), 'A female style in corporate leadership? evidence from quotas', American Economic Journal: Applied Economics 5(3), 136 Ü169.

McCue, K. (1996), 'Promotions and wage growth', Journal of Labor Economics 14(2), 175-209.

Niederle, M. and Vesterlund, L. (2007), 'Do women shy away from competition? Do men compete too much?', Quarterly Journal of Economics 122(3), 1067-1101.

Oberschachtsiek, D., Scioch, P., Seysenand, C. and Heining, J. (2009), Stichprobe der Integrierten Erwerbsbiographien IEBS - Handbuch für die IEBS in der Fassung 2008, FDZ Datenreport 03/2009 (de), Research Data Centre (FDZ) of the Federal Employment Service and the Institute for Employment Research, Nürnberg.

Papke, L. E. and Wooldridge, J. M. (2008), 'Panel data methods for fractional response variables with an application to test pass rates', Journal of Econometrics 145, 121-133.

Parrotta, P. and Smith, N. (2013), Why so few women on boards of directors? Empirical evidence from Danish companies 1997-2007, IZA Discussion Paper No. 7678, Institute for the Study of Labor, Bonn.

Prowse, V. (2013), 'Modeling employment dynamics with state dependence and unobserved heterogeneity', Journal of Business and Economics Statistics 30(3), 411-431.

Rabe-Hesketh, S. and Skrondal, A. (2013), 'Avoiding biased versions of wooldridgeŠs simple solution to the initial conditions problem', Economics Letters 120, 346349. 
Roodman, D. (2009), 'A note on the theme of too many instruments', Oxford Bulletin of Economics and Statistics 71(1), 135-158.

Ruud, P. (1984), 'Tests of specification in econometrics', Econometric Reviews 3, 211-242.

Saygin, P. O., Weber, A. and Weynandt, M. A. (2014), Coworkers, Networks, and Job Search Outcomes, IZA Discussion Paper No. 8174, Institute for the Study of Labor, Bonn.

Schein, V. E. (1973), 'The relationship between sex role stereotypes and requisite management characteristics', Journal of Organizational Behavior 13(5), 95100.

Schein, V. E. and Mueller, R. (1992), 'Sex role stereotyping and requisite management characteristics: A cross cultural look', Journal of Organizational Behavior 13(5), 439-447.

Schnabel, C. (2016), 'United, yet apart? A note on persistent labour market differences between Western and EasEast Germany', Journal of Economics and Statistics 46, 93-114.

Smith, N., Smith, V. and Verner, M. (2013), 'Why are so few female promoted into CEO and vice president positions? Danish empirical evidence, 1997-2007', Industrial and Labor Relations Review 66, 380-408.

Windmejer, F. (2005), 'A finite sample correction for the variance of linear efficient two-step GMM estimators', Journal of Econometrics 126, 25-51.

Wooldridge, J. M. (2005), 'Simple solutions to the initial conditions problem in dynamic, nonlinear panel data models with unobserved heterogenity', Journal of Applied Econometrics 20(1), 39-54.

Wooldridge, J. M. (2010), Econometric Analysis of Cross Section and Panel Data, 2nd edn, The MIT Press, Massachussetts. 


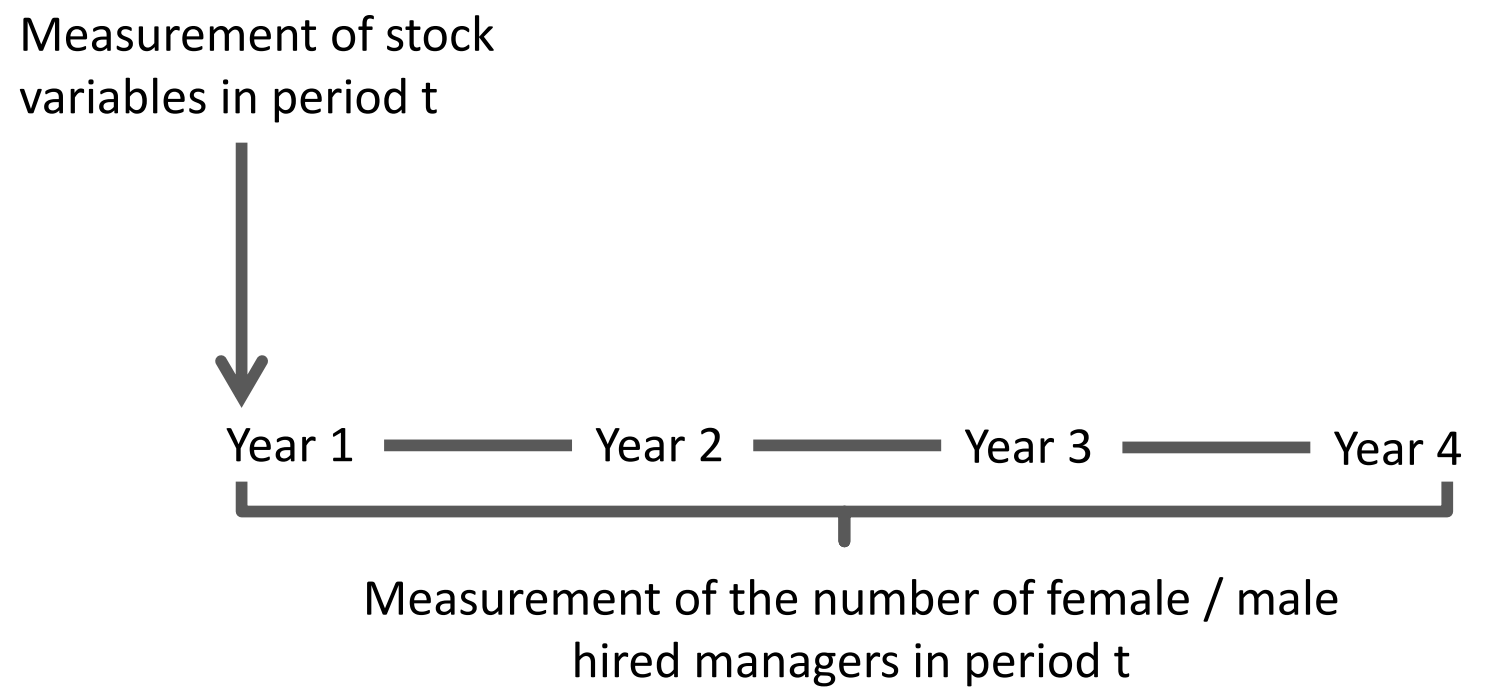

Figure 1: Measurement of variables 
Table 1: Variable means by number of female hired managers, Regression Sample 1

\begin{tabular}{|c|c|c|c|c|c|c|c|}
\hline & \multicolumn{6}{|c|}{ Number of female hired managers in period $t$} & \multirow[b]{2}{*}{ All } \\
\hline & 0 & $1-4$ & $5-9$ & $10-19$ & $20-49$ & $50+$ & \\
\hline \multicolumn{8}{|l|}{ Number of ... } \\
\hline employees & 226.0 & 437.0 & 863.2 & $1,404.7$ & $2,887.6$ & $5,175.7$ & 299.1 \\
\hline female managers & 0.3 & 1.6 & 6.2 & 13.0 & 27.3 & 90.0 & 1.0 \\
\hline male managers & 4.1 & 10.8 & 31.9 & 58.1 & 122.7 & 397.5 & 7.1 \\
\hline female hires & 42.4 & 92.2 & 189.2 & 296.0 & 523.1 & 1001.0 & 60.12 \\
\hline male hires & 65.0 & 123.2 & 249.5 & 385.3 & 750.6 & 1745.6 & 87.54 \\
\hline female hired managers & 0.0 & 1.6 & 6.4 & 13.4 & 29.8 & 126.1 & 0.8 \\
\hline male hired managers & 1.3 & 4.8 & 15.8 & 30.4 & 71.3 & 302.2 & 3.1 \\
\hline female separations & 46.4 & 98.9 & 196.0 & 295.6 & 494.1 & 941.2 & 62.9 \\
\hline male separations & 75.8 & 141.7 & 275.9 & 434.2 & 830.5 & $1,790.2$ & 98.6 \\
\hline female separated managers & 0.1 & 1.3 & 5.6 & 11.3 & 24.0 & 104.1 & 0.8 \\
\hline male separated managers & 2.1 & 6.3 & 20.4 & 35.8 & 76.5 & 308.2 & 4.3 \\
\hline female promotions & 0.1 & 0.3 & 1.2 & 3.1 & 6.3 & 32.6 & 0.2 \\
\hline male promotions & 0.5 & 1.6 & 5.3 & 11.8 & 29.8 & 143.9 & 1.1 \\
\hline Female share of managers & 0.088 & 0.188 & 0.264 & 0.302 & 0.308 & 0.284 & 0.111 \\
\hline Female share of non-managers & 0.355 & 0.436 & 0.480 & 0.494 & 0.503 & 0.448 & 0.373 \\
\hline Share of high qualified employees & 0.052 & 0.095 & 0.156 & 0.208 & 0.225 & 0.346 & 0.064 \\
\hline Year of plant foundation & 1978.4 & 1979.5 & 1980.5 & 1980.5 & 1980.1 & 1979.7 & 1978.6 \\
\hline \multicolumn{8}{|l|}{ Urbanization: } \\
\hline Metropolitan & 0.340 & 0.436 & 0.567 & 0.590 & 0.681 & 0.664 & 0.364 \\
\hline Metropolitan surroundings & 0.449 & 0.409 & 0.364 & 0.350 & 0.277 & 0.313 & 0.439 \\
\hline Urbanized & 0.129 & 0.097 & 0.047 & 0.044 & 0.035 & 0.018 & 0.121 \\
\hline Rural & 0.082 & 0.058 & 0.022 & 0.017 & 0.006 & 0.005 & 0.076 \\
\hline \multicolumn{8}{|l|}{ Time period: } \\
\hline 1979-1982 & 0 & 0 & 0 & 0 & 0 & 0 & 0 \\
\hline $1983-1986$ & 0.164 & 0.083 & 0.049 & 0.025 & 0.029 & 0.032 & 0.146 \\
\hline $1987-1990$ & 0.180 & 0.113 & 0.074 & 0.056 & 0.066 & 0.065 & 0.165 \\
\hline 1991-1994 & 0.167 & 0.142 & 0.112 & 0.122 & 0.108 & 0.078 & 0.161 \\
\hline 1995-1998 & 0.151 & 0.159 & 0.156 & 0.127 & 0.164 & 0.111 & 0.152 \\
\hline 1999-2002 & 0.126 & 0.182 & 0.215 & 0.229 & 0.217 & 0.230 & 0.138 \\
\hline 2003-2006 & 0.118 & 0.168 & 0.187 & 0.202 & 0.180 & 0.217 & 0.129 \\
\hline $2007-2010$ & 0.095 & 0.153 & 0.206 & 0.238 & 0.236 & 0.267 & 0.109 \\
\hline Number of observations & 117,563 & 26,136 & 2,665 & 1,067 & 483 & 217 & 148,131 \\
\hline Share of observations & 0.793 & 0.176 & 0.018 & 0.007 & 0.003 & 0.001 & 1 \\
\hline Number of plants & 31,522 & 13,828 & 1,844 & 732 & 298 & 97 & 33,237 \\
\hline
\end{tabular}

Data source: Integrated Employment Biographies. There are no observations in the first period because estimations of the number of female manager hires contain one lag of the dependent variable. Note that the sum of the number of plants in the first six columns exceeds the number in the seventh column since plants may change through time between categories. 
Table 2: Dynamic linear models; dependent variable: Number of female hired managers

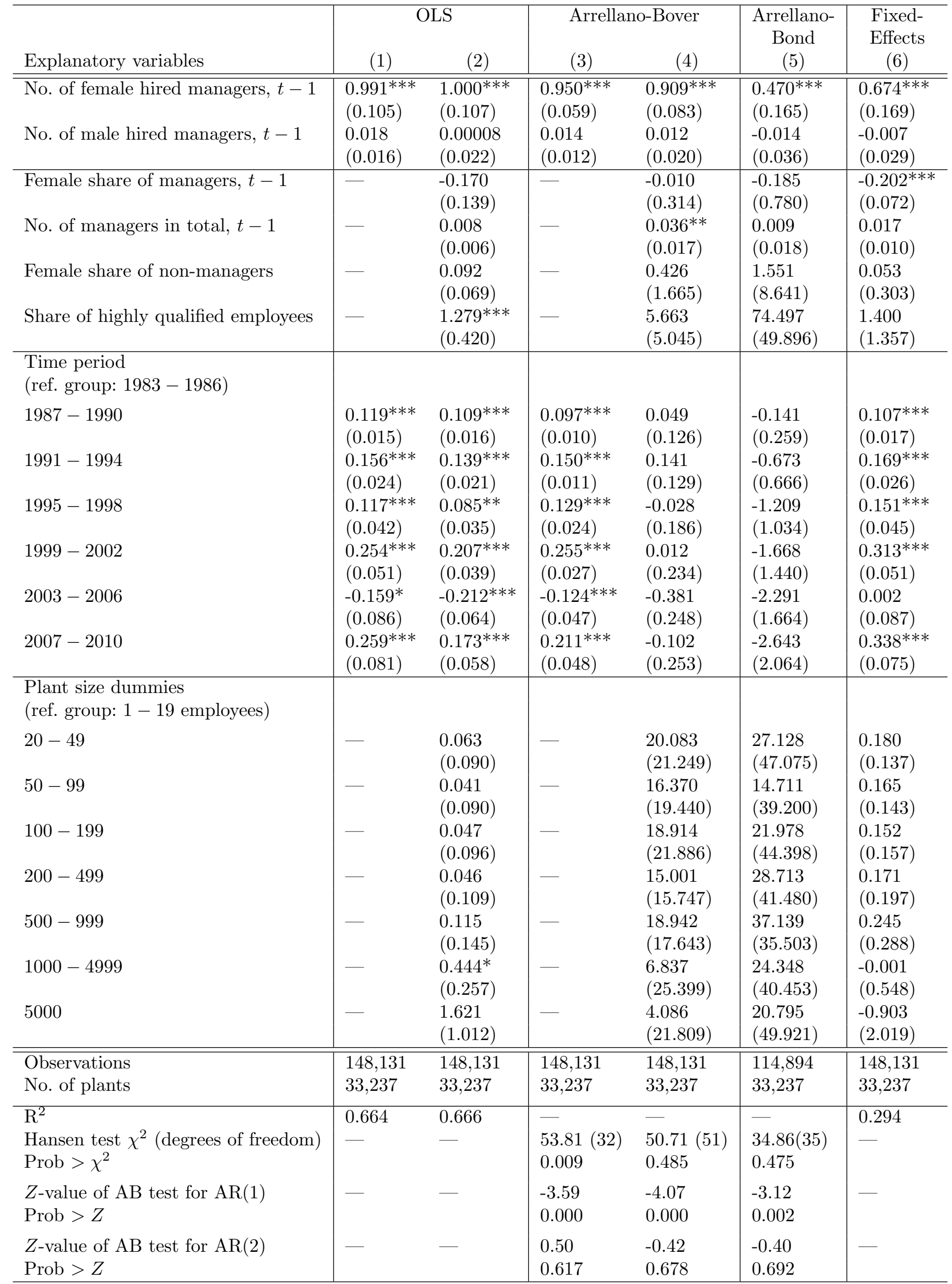

Data source: Integrated Employment Biographies. *,**, *** denotes significance at the 10\%, 5\% and 1\% level. Standard errors of models (1), (2) and (6) are clustered at the plant level. Standard errors of models (3), (4) and (5) are calculated using the method of Windmejer (2005). Model (2) additionally includes nine region dummies (Bundesland), seven sector dummies, three urbanisation dummies and the year of foundation of the plant. $f_{i t-2}, f_{i t-3}, m_{i t-2}, m_{i t-3}, \mathbf{x}_{i t-1}, \ldots, \mathbf{x}_{i 1}$ are used as instruments for the differenced equation. $\Delta f_{i t-1}, \Delta f_{i t-2}, \Delta m_{i t-1}, \Delta m_{i t-2}, \Delta \mathbf{x}_{i t}, \ldots, \Delta \mathbf{x}_{i 2}$ are used as instruments for the levels equation. Plant size dummies excluded in each case from the instrument list. 
Table 3: Dynamic linear models; dependent variable: Number of female hired managers; separations and promotions included as controls

\begin{tabular}{|c|c|c|c|}
\hline \multirow[b]{2}{*}{ Explanatory variables } & \multicolumn{3}{|c|}{ Arrellano-Bover } \\
\hline & $(7)$ & $(8)$ & $(9)$ \\
\hline No. of female hired managers, $t-1$ & $\begin{array}{l}1.042^{* * *} \\
(0.113)\end{array}$ & - & $\begin{array}{l}0.956^{* * *} \\
(0.099)\end{array}$ \\
\hline No. of male hired managers, $t-1$ & $\begin{array}{l}-0.010 \\
(0.021)\end{array}$ & - & $\begin{array}{l}-0.008 \\
(0.022)\end{array}$ \\
\hline No. of female separated managers, $t-1$ & $\begin{array}{c}-0.197^{*} \\
(0.107)\end{array}$ & - & - \\
\hline No. of male separated managers, $t-1$ & $\begin{array}{l}-0.026 \\
(0.031)\end{array}$ & - & - \\
\hline Female hired managers - female separated managers, $t-1$ & - & $\begin{array}{l}0.543^{* * *} \\
(0.111)\end{array}$ & - \\
\hline Male hired managers - male separated managers, $t-1$ & - & $\begin{array}{l}0.090^{*} \\
(0.047)\end{array}$ & - \\
\hline Promoted female managers, $t-1$ & - & - & $\begin{array}{l}0.099^{* *} \\
(0.048)\end{array}$ \\
\hline Promoted male managers, $t-1$ & - & - & $\begin{array}{l}0.036 \\
(0.024)\end{array}$ \\
\hline Female share of managers, $t-1$ & $\begin{array}{l}0.358 \\
(0.556)\end{array}$ & $\begin{array}{l}1.076 \\
(1.330)\end{array}$ & $\begin{array}{l}-0.007 \\
(0.649)\end{array}$ \\
\hline No. of managers in total, $t-1$ & $\begin{array}{l}0.045 \\
(0.035)\end{array}$ & $\begin{array}{l}0.141^{* * *} \\
(0.044)\end{array}$ & $\begin{array}{l}0.024^{*} \\
(0.013)\end{array}$ \\
\hline Female share of non-managers & $\begin{array}{l}0.508 \\
(3.059)\end{array}$ & $\begin{array}{l}3.830 \\
(6.696)\end{array}$ & $\begin{array}{l}0.516 \\
(2.740)\end{array}$ \\
\hline Share of highly qualified employees & $\begin{array}{l}5.773 \\
(6.842)\end{array}$ & $\begin{array}{l}1.150 \\
(16.179)\end{array}$ & $\begin{array}{l}-0.128 \\
(5.327)\end{array}$ \\
\hline $\begin{array}{l}\text { Observations } \\
\text { No. of plants }\end{array}$ & $\begin{array}{l}148,131 \\
33,237\end{array}$ & $\begin{array}{l}148,131 \\
33,237\end{array}$ & $\begin{array}{l}148,131 \\
33,237\end{array}$ \\
\hline $\begin{array}{l}\text { Hansen test } \chi^{2} \text { (degrees of freedom) } \\
\text { Prob }>\chi^{2}\end{array}$ & $\begin{array}{l}73.72(83) \\
0.757\end{array}$ & $\begin{array}{l}34.76(51) \\
0.960\end{array}$ & $\begin{array}{l}65.95(83) \\
0.915\end{array}$ \\
\hline $\begin{array}{l}Z \text {-value of } \mathrm{AB} \text { test for } \mathrm{AR}(1) \\
\text { Prob }>Z\end{array}$ & $\begin{array}{l}-3.92 \\
0.000\end{array}$ & $\begin{array}{l}-1.76 \\
0.078\end{array}$ & $\begin{array}{l}-2.84 \\
0.005\end{array}$ \\
\hline $\begin{array}{l}Z \text {-value of } \mathrm{AB} \text { test for } \mathrm{AR}(2) \\
\text { Prob }>Z\end{array}$ & $\begin{array}{l}0.41 \\
0.682\end{array}$ & $\begin{array}{l}-0.42 \\
0.674\end{array}$ & $\begin{array}{l}-0.64 \\
0.521\end{array}$ \\
\hline
\end{tabular}

Data source: Integrated Employment Biographies. * , **, *** denotes significance at the 10\%, 5\% and $1 \%$ level. All models additionally include seven plant size dummies and six time dummies. Standard errors are calculated using the method of Windmejer (2005). $f_{i t-2}, f_{i t-3}, m_{i t-2}$, $m_{i t-3}, \mathbf{x}_{i t-1}, \ldots, \mathbf{x}_{i 1}$ are used as instruments for the differenced equation. $\Delta f_{i t-1}, \Delta f_{i t-2}$, $\Delta m_{i t-1}, \Delta m_{i t-2}, \Delta \mathbf{x}_{i t}, \ldots, \Delta \mathbf{x}_{i 2}$ are used as instruments for the levels equation. Plant size dummies excluded in each case from the instrument list. 
Table 4: Dynamic linear models; dependent variables: Number of female hired and promoted managers; separations and promotions included as controls

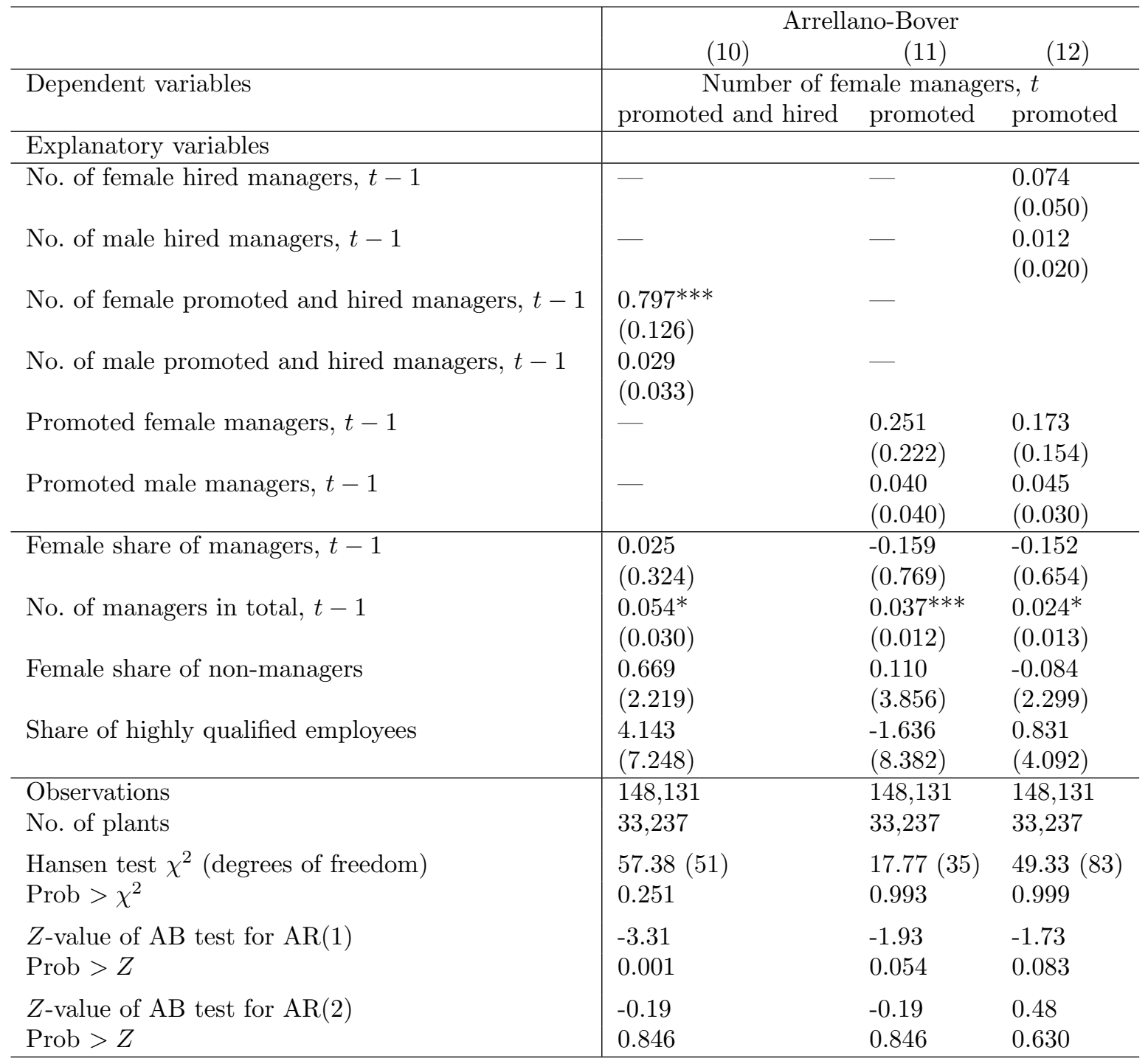

Data source: Integrated Employment Biographies. ${ }^{*},{ }^{* *},{ }^{* * *}$ denotes significance at the 10\%, 5\% and $1 \%$ level. Standard errors are calculated using the method of Windmejer (2005). All models additionally include seven plant size dummies and six time dummies. $f_{i t-2}, f_{i t-3}, m_{i t-2}, m_{i t-3}$, $\mathbf{x}_{i t-1}, \ldots, \mathbf{x}_{i 1}$ are used as instruments for the differenced equation. $\Delta f_{i t-1}, \Delta f_{i t-2}, \Delta m_{i t-1}$, $\Delta m_{i t-2}, \Delta \mathbf{x}_{i t}, \ldots, \Delta \mathbf{x}_{i 2}$ are used as instruments for the levels equation. Plant size dummies excluded in each case from the instrument list. 
Table 5: Dynamic linear models; dependent variable: Number of male hired managers

\begin{tabular}{|c|c|c|c|c|c|c|}
\hline Explanatory variables & \multicolumn{2}{|c|}{ OLS } & \multicolumn{2}{|c|}{ Arrellano-Bover } & $\begin{array}{l}\text { Arrellano- } \\
\text { Bond } \\
(17)\end{array}$ & $\begin{array}{l}\text { Fixed- } \\
\text { Effects } \\
(18)\end{array}$ \\
\hline No. of male hired managers, $t-1$ & $\begin{array}{l}0.816^{* * *} \\
(0.071)\end{array}$ & $\begin{array}{l}0.628^{* * *} \\
(0.102)\end{array}$ & $\begin{array}{l}0.697^{* * *} \\
(0.137)\end{array}$ & $\begin{array}{l}0.651^{* * *} \\
(0.130)\end{array}$ & $\begin{array}{l}0.241 \\
(0.171)\end{array}$ & $\begin{array}{l}0.330^{* *} \\
(0.146)\end{array}$ \\
\hline No. of female hired managers, $t-1$ & $\begin{array}{l}0.129 \\
(0.173)\end{array}$ & $\begin{array}{l}0.240 \\
(0.210)\end{array}$ & $\begin{array}{l}0.291 \\
(0.256)\end{array}$ & $\begin{array}{l}-0.023 \\
(0.258)\end{array}$ & $\begin{array}{l}-0.292 \\
(0.547)\end{array}$ & $\begin{array}{l}0.014 \\
(0.304)\end{array}$ \\
\hline Male share of managers, $t-1$ & - & $\begin{array}{l}0.445 \\
(0.281)\end{array}$ & - & $\begin{array}{l}0.974 \\
(1.416)\end{array}$ & $\begin{array}{l}-0.229 \\
(2.747)\end{array}$ & $\begin{array}{l}0.267^{*} \\
(0.148)\end{array}$ \\
\hline No. of managers in total, $t-1$ & - & $\begin{array}{l}0.092^{* * *} \\
(0.019)\end{array}$ & - & $\begin{array}{l}0.154^{* * *} \\
(0.041)\end{array}$ & $\begin{array}{l}0.001 \\
(0.060)\end{array}$ & $\begin{array}{l}0.056^{* *} \\
(0.024)\end{array}$ \\
\hline Female share of non-managers & - & $\begin{array}{l}-0.174 \\
(0.131)\end{array}$ & - & $\begin{array}{l}2.673 \\
(5.614)\end{array}$ & $\begin{array}{l}-3.579 \\
(36.513)\end{array}$ & $\begin{array}{l}-0.915 \\
(0.772)\end{array}$ \\
\hline Share of highly qualified employees & - & $\begin{array}{l}4.168^{* * *} \\
(1.208)\end{array}$ & - & $\begin{array}{l}22.783^{*} \\
(13.837)\end{array}$ & $\begin{array}{l}-34.147 \\
(159.942)\end{array}$ & $\begin{array}{l}2.085 \\
(2.774)\end{array}$ \\
\hline \multicolumn{7}{|l|}{$\begin{array}{l}\text { Time period } \\
\text { (ref. group: } 1983-1986 \text { ) }\end{array}$} \\
\hline $1987-1990$ & $\begin{array}{l}0.566^{* * *} \\
(0.061)\end{array}$ & $\begin{array}{l}0.494^{* * *} \\
(0.063)\end{array}$ & $\begin{array}{l}0.473^{* * *} \\
(0.057)\end{array}$ & $\begin{array}{l}0.106 \\
(0.428)\end{array}$ & $\begin{array}{l}0.518 \\
(0.852)\end{array}$ & $\begin{array}{l}0.427 * * * \\
(0.067)\end{array}$ \\
\hline $1991-1994$ & $\begin{array}{l}0.404^{* * *} \\
(0.087)\end{array}$ & $\begin{array}{l}0.360^{* * *} \\
(0.081)\end{array}$ & $\begin{array}{l}0.343^{* * *} \\
(0.043)\end{array}$ & $\begin{array}{l}0.287 \\
(0.401)\end{array}$ & $\begin{array}{l}0.740 \\
(2.240)\end{array}$ & $\begin{array}{l}0.396^{* * *} \\
(0.097)\end{array}$ \\
\hline $1995-1998$ & $\begin{array}{l}0.391^{* * *} \\
(0.094)\end{array}$ & $\begin{array}{l}0.270^{* * *} \\
(0.096)\end{array}$ & $\begin{array}{l}0.302^{* * *} \\
(0.068)\end{array}$ & $\begin{array}{l}-0.039 \\
(0.555)\end{array}$ & $\begin{array}{l}0.972 \\
(3.562)\end{array}$ & $\begin{array}{l}0.386^{* * *} \\
(0.109)\end{array}$ \\
\hline $1999-2002$ & $\begin{array}{l}0.536^{* * *} \\
(0.140)\end{array}$ & $\begin{array}{l}0.349^{* *} \\
(0.152)\end{array}$ & $\begin{array}{l}0.396^{* * *} \\
(0.083)\end{array}$ & $\begin{array}{l}-0.202 \\
(0.677)\end{array}$ & $\begin{array}{l}1.214 \\
(5.157)\end{array}$ & $\begin{array}{l}0.520^{* * *} \\
(0.178)\end{array}$ \\
\hline $2003-2006$ & $\begin{array}{l}-0.482^{* * *} \\
(0.159)\end{array}$ & $\begin{array}{l}-0.697^{* * * *} \\
(0.153)\end{array}$ & $\begin{array}{l}-0.505^{* * *} \\
(0.128)\end{array}$ & $\begin{array}{l}-0.669 \\
(0.719)\end{array}$ & $\begin{array}{l}0.554 \\
(6.091)\end{array}$ & $\begin{array}{l}-0.335 \\
(0.210)\end{array}$ \\
\hline $2007-2010$ & $\begin{array}{l}0.334^{* *} \\
(0.150)\end{array}$ & $\begin{array}{l}-0.122 \\
(0.175)\end{array}$ & $\begin{array}{l}0.132 \\
(0.149)\end{array}$ & $\begin{array}{l}-0.250 \\
(0.762)\end{array}$ & $\begin{array}{l}0.838 \\
(7.551)\end{array}$ & $\begin{array}{l}-0.001 \\
(0.242)\end{array}$ \\
\hline \multicolumn{7}{|l|}{$\begin{array}{l}\text { Plant size dummies } \\
\text { (ref. group: } 1-19 \text { employees) }\end{array}$} \\
\hline $20-49$ & - & $\begin{array}{l}-0.116 \\
(0.343)\end{array}$ & - & $\begin{array}{l}91.266^{*} \\
(46.618)\end{array}$ & $\begin{array}{l}1.590 \\
(111.157)\end{array}$ & $\begin{array}{l}0.269 \\
(0.406)\end{array}$ \\
\hline $50-99$ & - & $\begin{array}{l}-0.234 \\
(0.339)\end{array}$ & - & $\begin{array}{l}88.532^{* *} \\
(45.016)\end{array}$ & $\begin{array}{l}-1.168 \\
(100.938)\end{array}$ & $\begin{array}{l}0.320 \\
(0.423)\end{array}$ \\
\hline $100-199$ & - & $\begin{array}{l}-0.181 \\
(0.350)\end{array}$ & - & $\begin{array}{l}73.340 \\
(45.416)\end{array}$ & $\begin{array}{l}5.009 \\
(98.664)\end{array}$ & $\begin{array}{l}0.390 \\
(0.473)\end{array}$ \\
\hline $200-499$ & - & $\begin{array}{l}-0.093 \\
(0.379)\end{array}$ & - & $\begin{array}{l}82.954^{* *} \\
(39.025)\end{array}$ & $\begin{array}{l}6.827 \\
(103.255)\end{array}$ & $\begin{array}{l}0.767 \\
(0.600)\end{array}$ \\
\hline $500-999$ & - & $\begin{array}{l}0.131 \\
(0.491)\end{array}$ & - & $\begin{array}{l}63.955^{*} \\
(37.635)\end{array}$ & $\begin{array}{l}-18.957 \\
(110.275)\end{array}$ & $\begin{array}{l}1.260 \\
(0.912)\end{array}$ \\
\hline $1000-4999$ & - & $\begin{array}{l}0.701 \\
(0.946)\end{array}$ & - & $\begin{array}{l}79.295 \\
(65.169)\end{array}$ & $\begin{array}{l}-10.995 \\
(96.739)\end{array}$ & $\begin{array}{l}2.328 \\
(1.959)\end{array}$ \\
\hline 5000 and more & - & $\begin{array}{l}9.075^{* *} \\
(3.539)\end{array}$ & - & $\begin{array}{l}48.315 \\
(80.847)\end{array}$ & $\begin{array}{l}-18.309 \\
(155.695) \\
\end{array}$ & $\begin{array}{l}-1.436 \\
(6.305)\end{array}$ \\
\hline $\begin{array}{l}\text { Observations } \\
\text { No. of plants }\end{array}$ & $\begin{array}{l}148,131 \\
33,237\end{array}$ & $\begin{array}{l}148,131 \\
33,237\end{array}$ & $\begin{array}{l}148,131 \\
33,237\end{array}$ & $\begin{array}{l}148,131 \\
33,237\end{array}$ & $\begin{array}{l}114,894 \\
33,237\end{array}$ & $\begin{array}{l}148,131 \\
33,237\end{array}$ \\
\hline $\begin{array}{l}\mathrm{R}^{2} \\
\text { Hansen test } \chi^{2} \text { (degrees of freedom) } \\
\text { Prob }>\chi^{2}\end{array}$ & $\begin{array}{l}0.664 \\
-\end{array}$ & $\begin{array}{l}0.666 \\
-\end{array}$ & $\begin{array}{l}- \\
54.74(32) \\
0.007\end{array}$ & $\begin{array}{l}\overline{-} \\
60.64(51) \\
0.167\end{array}$ & $\begin{array}{l}\overline{-} \\
28.40(35) \\
0.777\end{array}$ & $\begin{array}{l}0.294 \\
-\end{array}$ \\
\hline $\begin{array}{l}Z \text {-value of } \mathrm{AB} \text { test for } \mathrm{AR}(1) \\
\text { Prob }>Z\end{array}$ & - & - & $\begin{array}{l}-2.57 \\
0.010\end{array}$ & $\begin{array}{l}-2.89 \\
0.004\end{array}$ & $\begin{array}{l}-2.02 \\
0.043\end{array}$ & - \\
\hline $\begin{array}{l}Z \text {-value of } \mathrm{AB} \text { test for } \mathrm{AR}(2) \\
\text { Prob }>Z\end{array}$ & - & - & $\begin{array}{l}0.91 \\
0.361\end{array}$ & $\begin{array}{l}-0.12 \\
0.907\end{array}$ & $\begin{array}{l}-0.28 \\
0.777\end{array}$ & - \\
\hline
\end{tabular}

Data source: Integrated Employment Biographies. ${ }^{*},{ }^{* *},{ }^{* *}$ denotes significance at the $10 \%, 5 \%$ and $1 \%$ level. Standard errors of models (13), (14) and (18) are clustered at the plant level. Standard errors of models (15), (16) and (17) are calculated using the method of Windmejer (2005). Model (14) additionally includes nine region dummies (Bundesland), seven sector dummies, three urbanisation dummies and the year of foundation of the plant. $f_{i t-2}, f_{i t-3}, m_{i t-2}, m_{i t-3}, \mathbf{x}_{i t-1}, \ldots, \mathbf{x}_{i 1}$ are used as instruments for the differenced equation. $\Delta f_{i t-1}, \Delta f_{i t-2}, \Delta m_{i t-1}, \Delta m_{i t-2}, \Delta \mathbf{x}_{i t}, \ldots, \Delta \mathbf{x}_{i 2}$ are used as instruments for the levels equation. Plant size dummies excluded in each case from the instrument list. 
Table 6: Dynamic linear models; dependent variable: Female share of hired managers

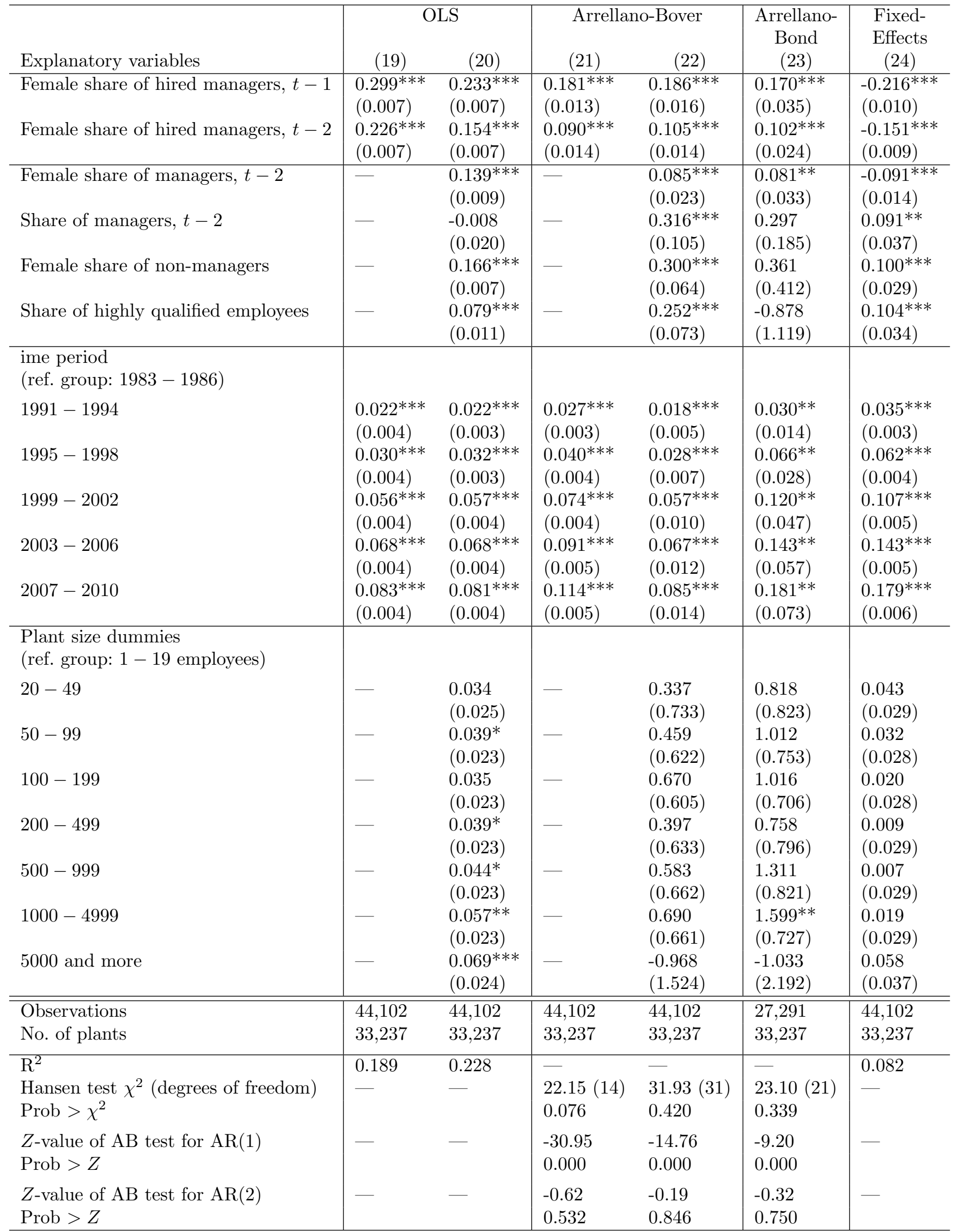

Data source: Integrated Employment Biographies. ${ }^{*},{ }^{* *},{ }^{* * *}$ denotes significance at the $10 \%, 5 \%$ and $1 \%$ level. Standard errors of models (19), (20) and (24) are clustered at the plant level. Standard errors of models (21), (22) and (23) are calculated using the method of Windmejer (2005). Model (20) additionally includes nine region dummies (Bundesland), seven sector dummies, three urbanisation dummies and the year of foundation of the plant. $f_{i t-2}, f_{i t-3}, m_{i t-2}, m_{i t-3}, \mathbf{x}_{i t-1}, \ldots, \mathbf{x}_{i 1}$ are used as instruments for the differenced equation. $\Delta f_{i t-1}$, $\Delta f_{i t-2}, \Delta m_{i t-1}, \Delta m_{i t-2}, \Delta \mathbf{x}_{i t}, \ldots, \Delta \mathbf{x}_{i 2}$ are used as instruments for the levels equation. Plant size dummies excluded in each case from the instrument list. 
Table 7: Dynamic tobit models; dependent variable: Female share of hired managers; average partial effects (APE)

\begin{tabular}{|c|c|c|c|c|}
\hline \multirow[b]{2}{*}{ Explanatory variables } & \multicolumn{2}{|c|}{ Dynamic pooled tobit models } & \multicolumn{2}{|c|}{$\begin{array}{l}\text { Dynamic tobit models with } \\
\text { random effects }\end{array}$} \\
\hline & $(25)$ & $(26)$ & $(27)$ & $(28)$ \\
\hline Female share of hired managers, $t-1$ & $\begin{array}{l}0.247^{* * *} \\
(0.005)\end{array}$ & $\begin{array}{l}0.185^{* * *} \\
(0.005)\end{array}$ & $\begin{array}{l}0.060^{* * *} \\
(0.007)\end{array}$ & $\begin{array}{l}0.071^{* * *} \\
(0.007)\end{array}$ \\
\hline Female share of hired managers, $t-2$ & $\begin{array}{l}0.179 * * * \\
(0.005)\end{array}$ & $\begin{array}{l}0.115^{* * *} \\
(0.005)\end{array}$ & $\begin{array}{l}0.032^{* * *} \\
(0.006)\end{array}$ & $\begin{array}{l}0.028^{* * *} \\
(0.006)\end{array}$ \\
\hline $\begin{array}{l}\text { Female share of hired managers, } t=0 \\
\text { Female share of hired managers, } t=1\end{array}$ & - & - & $\begin{array}{l}0.134^{* * *} \\
(0.007) \\
0.163^{* * *} \\
(0.008)\end{array}$ & $\begin{array}{l}0.038^{* * *} \\
(0.007) \\
0.074^{* * *} \\
(0.008)\end{array}$ \\
\hline Female share of managers, $t-2$ & - & $\begin{array}{l}0.097^{* * *} \\
(0.006) \\
0.125 * * *\end{array}$ & - & $\begin{array}{l}-0.070^{* * *} \\
(0.009)\end{array}$ \\
\hline Share of managers, $t-2$ & - & $\begin{array}{l}0.135^{* * *} \\
(0.018)\end{array}$ & - & $\begin{array}{l}-0.030 \\
(0.035)\end{array}$ \\
\hline Female share of non-managers & - & $\begin{array}{l}0.170^{* * *} \\
(0.006)\end{array}$ & - & $\begin{array}{l}0.031 \\
(0.022)\end{array}$ \\
\hline Share of highly qualified employees & - & $\begin{array}{l}0.141^{* * *} \\
(0.010)\end{array}$ & - & $\begin{array}{l}0.027 \\
(0.028)\end{array}$ \\
\hline \multicolumn{5}{|l|}{$\begin{array}{l}\text { Size dummies } \\
\text { (ref. group: } 1-19 \text { employees) }\end{array}$} \\
\hline $20-49$ & - & $\begin{array}{l}0.035^{* *} \\
(0.016)\end{array}$ & - & $\begin{array}{l}0.023 \\
(0.022)\end{array}$ \\
\hline $50-99$ & - & $\begin{array}{l}0.032 * * \\
(0.015)\end{array}$ & - & $\begin{array}{l}0.014 \\
(0.021)\end{array}$ \\
\hline $100-199$ & - & $\begin{array}{l}0.040^{* * *} \\
(0.015)\end{array}$ & - & $\begin{array}{l}0.004 \\
(0.021)\end{array}$ \\
\hline $200-499$ & - & $\begin{array}{l}0.059^{* * *} \\
(0.015)\end{array}$ & - & $\begin{array}{l}-0.004 \\
(0.021)\end{array}$ \\
\hline $500-999$ & - & $\begin{array}{l}0.079^{* * *} \\
(0.015)\end{array}$ & - & $\begin{array}{l}0.0001 \\
(0.022)\end{array}$ \\
\hline $1000-4999$ & - & $\begin{array}{l}0.116^{* * *} \\
(0.016)\end{array}$ & - & $\begin{array}{l}0.020 \\
(0.023)\end{array}$ \\
\hline 5000 and more & - & $\begin{array}{l}0.184^{* * *} \\
(0.020)\end{array}$ & - & $\begin{array}{l}0.050 \\
(0.036)\end{array}$ \\
\hline \multicolumn{5}{|l|}{ Individual averages $\left(\overline{\boldsymbol{x}}_{i}\right)$} \\
\hline Female share of managers, $t-2$ & - & - & - & $\begin{array}{l}0.281^{* * *} \\
(0.013)\end{array}$ \\
\hline Share of managers, $t-2$ & - & - & - & $\begin{array}{l}0.235^{* * *} \\
(0.043)\end{array}$ \\
\hline Female share of non-managers & - & - & - & $\begin{array}{l}0.149^{* * *} \\
(0.023)\end{array}$ \\
\hline Share of highly qualified employees & - & - & - & $\begin{array}{l}0.131^{* * *} \\
(0.030)\end{array}$ \\
\hline$\sigma_{\varepsilon}$ (coefficient) & $\begin{array}{l}0.498^{* * *} \\
(0.003)\end{array}$ & $\begin{array}{l}0.482^{* * *} \\
(0.003)\end{array}$ & $\begin{array}{l}0.428^{* * *} \\
(0.003)\end{array}$ & $\begin{array}{l}0.437^{* * *} \\
(0.008)\end{array}$ \\
\hline$\sigma_{\xi}($ coefficient $)$ & - & - & $\begin{array}{l}0.296^{* * *} \\
(0.006)\end{array}$ & $\begin{array}{l}0.216^{* * *} \\
(0.008)\end{array}$ \\
\hline Observations & 38,077 & 38,077 & 38,077 & 38,077 \\
\hline No. of plants & 10,786 & 10,786 & 10,786 & 10,786 \\
\hline $\begin{array}{l}\text { Wald-test- } \chi^{2} \text { (degrees of freedom) } \\
\text { Prob }>\chi^{2}\end{array}$ & $\begin{array}{l}1046.55(7) \\
0.000\end{array}$ & $\begin{array}{l}247.57(38) \\
0.000\end{array}$ & $\begin{array}{l}4180.28(9) \\
0.000\end{array}$ & $\begin{array}{l}7176.67(51) \\
0.000\end{array}$ \\
\hline
\end{tabular}

Data source: Integrated Employment Biographies. ${ }^{*},{ }^{* *},{ }^{* * *}$ denotes significance at the $10 \%, 5 \%$ and $1 \%$ level. Average partial effects. All models include additionally five period dummies. Models (26) and (28) additionally include nine region dummies (Bundesland), seven sector dummies; three urbanisation dummies and the year of foundation of the plant. Model (28) additionally includes the plant averages of the size dummies. 